OPEN ACCESS

Edited by:

Ali Mobasheri,

University of Surrey, UK

Reviewed by:

Alessandro Sardini,

Imperial College London, UK

Jonathan Lippiat,

University of Leeds, UK

Habibeh Khoshbouei,

Univeristy of Florida, USA

Sarika Chaudhary

CSIR-Institute of Genomics and

Integrative Biology, India

*Correspondence:

Chris Gehring

christoph.gehring@kaust.edu.sa;

c.a.gehring@molecular-signals.com

Specialty section:

This article was submitted to

Membrane Physiology and Membrane

Biophysics,

a section of the journal

Frontiers in Physiology

Received: 07 April 2016

Accepted: 28 June 2016

Published: 19 July 2016

Citation:

Ooi A, Wong A, Esau L,

Lemtiri-Chlieh F and Gehring C (2016)

A Guide to Transient Expression of

Membrane Proteins in HEK-293 Cells

for Functional Characterization.

Front. Physiol. 7:300

doi: 10.3389/fphys.2016.00300

\section{A Guide to Transient Expression of Membrane Proteins in HEK-293 Cells for Functional Characterization}

\author{
Amanda Ooi ${ }^{1}$, Aloysius Wong ${ }^{1,2}$, Luke Esau ${ }^{1}$, Fouad Lemtiri-Chlieh ${ }^{1}$ and Chris Gehring ${ }^{1 *}$ \\ ${ }^{1}$ Division of Biological and Environmental Sciences and Engineering, King Abdullah University of Science and Technology, \\ Thuwal, Saudi Arabia, ${ }^{2}$ Institute of Integrative Biology of the Cell, Centre National de la Recherche Scientifique, Le \\ Commissariat à l'Energie Atomique et aux Energies Alternatives, Paris-Sud University, Gif-Sur-Yvette, France
}

The human embryonic kidney 293 (HEK-293) cells are commonly used as host for the heterologous expression of membrane proteins not least because they have a high transfection efficiency and faithfully translate and process proteins. In addition, their cell size, morphology and division rate, and low expression of native channels are traits that are particularly attractive for current-voltage measurements. Nevertheless, the heterologous expression of complex membrane proteins such as receptors and ion channels for biological characterization and in particular for single-cell applications such as electrophysiology remains a challenge. Expression of functional proteins depends largely on careful step-by-step optimization that includes the design of expression vectors with suitable identification tags, as well as the selection of transfection methods and detection parameters appropriate for the application. Here, we use the heterologous expression of a plant potassium channel, the Arabidopsis thaliana guard cell outward-rectifying $\mathrm{K}^{+}$channel, AtGORK (At5G37500) in HEK-293 cells as an example, to evaluate commonly used transfection reagents and fluorescent detection methods, and provide a detailed methodology for optimized transient transfection and expression of membrane proteins for in vivo studies in general and for single-cell applications in particular. This optimized protocol will facilitate the physiological and cellular characterization of complex membrane proteins.

Keywords: transfection, heterologous expression, membrane proteins, human embryonic kidney 293 cells, fluorescent imaging, electrophysiology

\section{INTRODUCTION}

Mammalian cells such as the human embryonic kidney 293 (HEK-293) and the Chinese hamster ovary $(\mathrm{CHO})$ cells are widely used as hosts to express recombinant proteins to study their structural, biophysical, and pharmacological properties (Baldi et al., 2007; Dalton and Barton, 2014). HEK-293 cells in particular are an attractive heterologous system for expression of membrane proteins not least because they have post-translational modification machineries required for the proper folding and/or optimal biological activity of target proteins. They also exhibit high transfection efficiency, faithful translation, and processing of proteins (Wurm, 2004) that will result in higher protein yields (Backliwal et al., 2008a) as compared to other mammalian cells, e.g., CHO cells (Bollin et al., 2011). These attributes together with the cell size, morphology, rapid division rate, the ease of maintenance, and the low expression of native channels as well as the capacity to express 
transgenic receptor proteins and ion channels with high fidelity (Thomas and Smart, 2005), have established HEK-293 cells as a host of choice for transient heterologous expression of membrane proteins for structural studies (Nettleship et al., 2008; Chaudhary et al., 2011; Andrell and Tate, 2013), biopharmaceutical (Thomas and Smart, 2005; Jager et al., 2013), and electrophysiology applications (Lemtiri-Chlieh and Ali, 2013).

Despite these advantages, high-level expression of complex membrane proteins such as ion channels and trans-membrane receptors originating from a different species for current-voltage measurements has remained a challenge (Gan et al., 2006; Allen et al., 2009). For electrophysiology in particular, a high expression of proteins is critical for single-cell current recordings in the whole-cell mode. Membrane protein biosynthesis in the host is limited by the different composition of lipid bilayers between human and other species that may prevent proper folding of expressed proteins into their functional native threedimensional conformations. As such, optimization of plasmids, culture media, growth conditions, or combinations thereof have been undertaken in the past to enhance the expression of membrane proteins (for review, see Jäger et al., 2015). These include the introduction of mild hypothermia (Wulhfard et al., 2008; Lin et al., 2015) and the addition of inhibitors of histone deacetylase to the culture media (Fan et al., 2005; Backliwal et al., 2008b). In addition to the essential elements required for the expression of recombinant protein, vectors can also be synthetically engineered to include optimized introns and codon usage (Gustafsson et al., 2004) and post-transcriptional regulatory elements (Mariati et al., 2010) to increase yields by stabilizing recombinant transcripts.

The delivery of the recombinant vector into the host cell and the detection of expressed proteins are the two critical stages crucial to the expression and study of recombinant proteins in HEK-293 cells. Recombinant proteins expressed in transiently transfected cells can be identified with a method that requires the simultaneous co-transfection of a lymphocyte surface marker antigen (CD8-alpha) or a fluorescent protein plasmid in addition to a second expression vector that contains the gene of interest (Lemtiri-Chlieh and Ali, 2013). This method enables visual identification of individual cells decorated with anti-CD8 antibody coated polystyrene beads (Jurman et al., 1994; Fortin and Hugo, 1999) under the light microscope or fluorescence detection of cells co-expressing the fluorescent proteins (Bestvater et al., 2002; Lin et al., 2015) and has been used for the study of ion channels and receptor proteins including the mammalian N-methyl-D-aspartate (NMDA; Ehlers et al., 1996) and $\alpha$-amino-3-hydroxy-5-methyl-4-isoxazolepropionic acid (AMPA) receptors (Swanson et al., 1997; Lin et al., 2015), the Arabidopsis thaliana cyclic nucleotide-gated ion channels (AtCNGCs) (Leng et al., 2002; Hua et al., 2003) and Arabidopsis $\mathrm{K}^{+}$transporters (AKTs) (Lacombe et al., 2000; Cherel et al., 2002). While simple, rapid and inexpensive, expression of the CD8-alpha marker antigen or the fluorescent protein in the transfected cells has no direct correlation with the transfection efficiency and expression of the recombinant protein as the success rate of the introduction of both these marker and target gene expression vectors into the cells may be highly variable. Recent methods using fluorescent tags such as a dyesensitive epitope (Tour et al., 2003; Rudner et al., 2005) or a fluorescent protein fusion (Snapp, 2005) provide a direct and better correlation between fluorescent signal and transfection efficiency and protein expression level although fusion tags such as fluorescent proteins may cause structural constrains that interfere with protein function. These fluorescent detection approaches have enabled successful expression of a number of membrane proteins including the connexin- 43 (Gaietta et al., 2002), the AMPA receptors (Ju et al., 2004), the G proteincoupled receptors (Hoffmann et al., 2005) and the human ether-a-go-go-related gene (hERG) channel (Claassen et al., 2008; Huang et al., 2011) that were subsequently used for protein localization and trafficking as well as current-voltage measurement studies.

Although the expression of several membrane proteins and ion channels in HEK-293 cells have been reported previously, a detailed authoritative protocol that describes the key stages in the transient transfection and in-cell detection of recombinant proteins optimized for single-cell applications, is currently lacking. Here, we use the transient expression of an A. thaliana guard cell outward-rectifying $\mathrm{K}^{+}$channel, AtGORK (At5G37500) in HEK-293 cells as an example to assess current commonly used transfection reagents and the fluorescent detection methods, and provide a specific protocol that is easily accessible for the general expression of membrane proteins in HEK-293 cells suitable for biological characterization. As an example, AtGORK represents: (1) a difficult to express multi-pass membrane protein, (2) originates from a different species, and (3) needs to assemble into a heteromeric complex to achieve functionality. These three characteristics can hamper optimal expression of membrane proteins in HEK cells. In addition to this authoritative step-by-step protocol, we also include cautionary measures, and propose optimization strategies and recommendations extendable and amendable for different applications or proteins.

\section{MATERIALS AND EQUIPMENT}

\section{Cell Line}

- Human Embryonic Kidney 293 (293FT) cell line (Cat. no. R70007, Life Technologies, Carlsbad, CA). The 293F cell line is a fast-growing variant of the 293 cell line originally obtained from Robert Horlick at Pharmacopeia while the 293T cell line is a variant of 293 cells that harbors the SV40 large T antigen which can bind to SV40 enhancers of expression vectors to increase protein production. Here, we use the 293FT cell line to leverage on both the "fast growing" and "increased protein production" benefits.

\section{Culture Media}

- Dulbecco's Modified Eagle's medium, DMEM (1X) + GlutaMAX $^{\mathrm{TM}}$-I (Cat. no. 31966021, Life Technologies Europe BVM, Bleiswijk, Netherlands).

- 10\% (v/v) Fetal Bovine Serum (Cat. no. 16000044, Life Technologies, Carlsbad, CA). 
- 1 (v/v) \% Penicillin-Streptomycin (10,000 U/mL; Cat. no. 15140122, Life Technologies Europe BVM, Bleiswijk, Netherlands).

- Opti-MEM ${ }^{\circledR}$ I Reduced Serum medium (Cat. no. 31985062, Life Technologies, Carlsbad, CA).

- Freezing medium consisting of $95 \%(\mathrm{v} / \mathrm{v})$ complete medium and $5 \%(\mathrm{v} / \mathrm{v})$ DMSO.

\section{Cloning Cells}

- One Shot ${ }^{\circledR} \quad$ Mach1 $1^{\mathrm{TM}}$ T1 phage-resistant chemically competent E. coli cells (Cat. no. C862003, Life Technologies, Carlsbad, CA).

\section{Vectors}

- Gateway ${ }^{\circledR}$ pDONR ${ }^{\mathrm{TM}} 221$ Vector (Cat. no. 12536017, Life Technologies, Carlsbad, CA).

- pcDNA $^{\mathrm{TM}} 6.2 /$ cLumio $^{\mathrm{TM}}$-DEST (Cat. no. 12589016, Invitrogen Corporation, Carlsbad, CA).

- pcDNA $^{\mathrm{TM}} 6.2 /$ nLumio $^{\mathrm{TM}}-G W / p 64$ (Cat. no. 12589016, Invitrogen Corporation, Carlsbad, CA).

- Vivid Colors ${ }^{\mathrm{TM}}$ pcDNA ${ }^{\mathrm{TM}} 6.2 /$ EmGFP-DEST Gateway ${ }^{\circledR}$ vector (Cat. no. V35520, Life Technologies, Carlsbad, CA).

- Vivid Colors pcDNA6.2/C-terminal tagged EmGFP/GW/CAT plasmids (Cat. no. V35520, Life Technologies, Carlsbad, CA).

\section{Chemicals/Reagents}

- Lipofectamine ${ }^{\circledR} 2000$ (Cat. no. 11668019, Life Technologies, Carlsbad, CA).

- Lipofectamine ${ }^{\circledR} 3000$ (Cat. no. L3000015, Life Technologies, Carlsbad, CA).

- FuGENE ${ }^{\circledR}$ HD formulation (Cat. no. E2311, Promega, Madison, WI).

- $0.25 \%$ Trypsin-EDTA solution (Cat. no. T4049, Sigma-Aldrich Chemie GmbH, Steinheim, Germany).

- 0.4\% Trypan Blue stain (Cat. no. T10282, Life Technologies, Carlsbad, CA).

- $50 \mu \mathrm{g} / \mathrm{mL}$ poly-D-lysine hydrobromide (Cat. no. P0899, Sigma-Aldrich, St. Louis, MO).

- Gateway ${ }^{\circledR}$ LR Clonase ${ }^{\circledR}$ II Enzyme Mix (Cat. no. 11791100, Invitrogen, Carlsbad, CA).

- Invitrogen ${ }^{\mathrm{TM}}$ PureLink ${ }^{\circledR}$ HQ Mini Plasmid Purification kit (Invitrogen $^{\mathrm{TM}}$, ThermoFisher Scientific, Carlsbad, CA).

- LB broth (Lennox) (Cat. no. L3022, Sigma-Aldrich Chemie $\mathrm{GmbH}$, Steinheim, Germany).

- Carbenicillin disodium salt (Cat. no. C3416, Sigma-Aldrich Chemie GmbH, Steinheim, Germany).

- Lumio $^{\mathrm{TM}}$ Green In-Cell Detection kit (Cat. No. 12589057, Life Technologies, Carlsbad, CA).

- 10X Phosphate Buffered Saline (PBS) solution (Cat. No. P5493, Sigma-Aldrich, St. Louis, MO).

- TRIzol ${ }^{\circledR}$ reagent (Cat. No. 15596026, Life Technologies, Carlsbad, CA).

- Applied Biosystems ${ }^{\mathrm{TM}}$ High-Capacity cDNA Reverse Transcription Kit (Cat.no. 4368814, Life Technologies, Carlsbad, CA).

- KAPA Taq PCR kit (Cat. no. KR0352, KAPA Biosystems, Wilmington, MA).
- Dimethyl sulfoxide (Cat. no. D8418, Sigma-Aldrich Chemie $\mathrm{GmbH}$, Steinheim, Germany).

- Acetone (Cat. no. 320110, Sigma-Aldrich, St. Louis, MO).

- Absolute ethanol (Cat. no. 32205, Sigma-Aldrich, St. Louis, $\mathrm{MO}$ ).

- Chloroform (Cat. no. 528730, Sigma-Aldrich Chemie GmbH, Steinheim, Germany).

- 2-Propanol (Cat. no. I9516, Sigma-Aldrich Chemie GmbH, Steinheim, Germany).

- DEPC-treated water (Cat. no. 95284, Sigma-Aldrich Chemie $\mathrm{GmbH}$, Steinheim, Germany).

\section{Buffer Preparation}

a) Intracellular solution consisting of $100 \mathrm{mM} \mathrm{KCl}, 25 \mathrm{mM}$ N-methyl-D-glucamine, $10 \mathrm{mM}$ HEPES, $10 \mathrm{mM}$ EGTA, $1 \mathrm{mM} \mathrm{CaCl}_{2}$, and $4 \mathrm{mM} \mathrm{MgCl} 2$ at $\mathrm{pH} 7.30$ and at $280 \pm$ 5 mOsm (osmolarity is adjusted by adding sorbitol). This solution is prepared a day before the patch-clamp experiment, filter sterilized through a $0.22 \mu \mathrm{m}$ Stericup-GP and stored at $4^{\circ} \mathrm{C}$.

b) External bath solution contained $10 \mathrm{mM} \mathrm{KCl}, 145 \mathrm{mM}$ $\mathrm{N}$-methyl-D-glucamine, $20 \mathrm{mM}$ HEPES, $10 \mathrm{mM}$ glucose, $0.5 \mathrm{mM} \mathrm{CaCl}_{2}$, and $1 \mathrm{mM} \mathrm{MgCl} 2$ at $\mathrm{pH} 7.30$ and at $310 \pm$ 5 mOsm (osmolarity is adjusted by adding sorbitol). This solution is prepared a day before the patch-clamp experiment, filter sterilized through a $0.22 \mu \mathrm{m}$ Stericup-GP and stored at $4^{\circ} \mathrm{C}$.

\section{Apparatus/Equipment}

- $75 \mathrm{~cm}^{2}, 250 \mathrm{~mL}$ Cellstar ${ }^{\circledR}$ cell culture flask (T-75; Cat. no. 658175, Greiner Bio-One GmbH, Frickenhausen, Germany).

- Corning ${ }^{\circledR}$ Costar $^{\circledR} 6$ well cell culture plates (Cat. no. 64705-01, Corning Inc., Brooklyn, NY).

- 15 mL Falcon ${ }^{\mathrm{TM}}$ conical centrifuge tubes (Cat. no. 14-959-70C, Corning Inc., Brooklyn, NY).

- Cryovials (Thermo Fisher Scientific, Waltham, MA).

- Stericup-GP, $0.22 \mu \mathrm{m}$, polyethersulfone, radio-sterilized (Cat. no. SCGPU05RE, Merck Millipore, Danver, MA).

- Countess ${ }^{\circledR}$ II Automated Cell Counter (Cat. no. AMQAX1000, Life Technologies, Carlsbad, CA).

- 5004 MICRO-OSMETTE ${ }^{\mathrm{TM}}$ automatic high sensitivity $50 \mu \mathrm{L}$ osmometer (PSi Precision Systems Inc., Natick, MA).

- Fisherbrand ${ }^{\mathrm{TM}} 12 \mathrm{~mm}$ circle cover glasses (Cat. no. 12-545-80, Fisher Scientific, Marietta, $\mathrm{OH}$ ).

- Thick/standard wall borosilicate glass capillaries (Cat. no. B150-86-10, Sutter Instrument ${ }^{\circledR}$, Novato, CA).

- Fluorescence microscope (Nikon Eclipse TS100, Melville, NY).

- P-1000 FLAMING/BROWN micropipette puller (Sutter instrument, Novato, CA).

- Microforge (Cat. no. MF-830, Narishige Group, Japan).

- Inverted microscope Carl Zeiss Axio Observer.A1 (Carl Zeiss, Oberkochen, Germany).

- MultiClamp ${ }^{\mathrm{TM}}$ 700B microelectrode amplifier (Axon Instruments, Molecular Devices, Sunnyvale, CA).

- Veriti ${ }^{\circledR}$ 96-Well Thermal Cycler (Cat. no. 4375786, Applied Biosystems $^{\mathrm{TM}}$, ThermoFisher Scientific, Carlsbad, CA). 
- New Brunswick ${ }^{\mathrm{TM}}$ Excella ${ }^{\circledR}$ E23/E24R benchtop incubator shaker (Eppendorf AG, Hamburg, Germany).

- 5\% carbon dioxide $\left(\mathrm{CO}_{2}\right)$ humidified growth incubator (Series $\mathrm{CB}, \mathrm{BINDER}$, Tuttlingen, Germany).

- Water bath (VWR International, Radnor, PA).

- Precision ${ }^{\mathrm{TM}}$ compact ovens (Thermo Fisher Scientific, Marietta, $\mathrm{OH})$.

- Nanodrop (Thermo Fisher Scientific, Marietta, OH.

\section{PROCEDURE}

\section{Design of Plasmid Construct (2-3 Days)}

1. Both pcDNA ${ }^{\mathrm{TM}} 6.2 / \mathrm{cLumio}^{\mathrm{TM}}$-DEST and Vivid Colors ${ }^{\mathrm{TM}}$ pcDNA $^{\mathrm{TM}} 6.2 /$ EmGFP-DEST Gateway ${ }^{\circledR}$ vector (Figure S1) are selected as the expression vectors to heterologously express the full-length $A$. thaliana GORK channel (AtGORK) (At5G37500) in HEK-293 cells.

2. The Lumio ${ }^{\mathrm{TM}}$ tag consisting of 6 amino acids is located at 27 amino acid residues downstream of the C-terminal of AtGORK (Figure S1A). The Lumio ${ }^{\mathrm{TM}}$ tag contains a tetracysteine motif (Cys-Cys-Pro-Gly-Cys-Cys) that forms an arsenical hairpin detectable by interactions with biarsenical labeling reagents (e.g., Lumio ${ }^{\mathrm{TM}}$ Green or $\mathrm{Lumio}^{\mathrm{TM}}$ Red; Griffin et al., 1998; Adams et al., 2002).

3. The Emerald Green Fluorescent Protein (EmGFP) derived from Aequorea victoria GFP (Tsien, 1998) is C-terminally tagged at the end of the AtGORK sequence in the mammalian expression clone (Figure S1B). Troubleshooting (Table 2).

4. Perform codon optimization of AtGORK sequences using the GeneOptimizer ${ }^{\circledR}$ software. - CRITICAL STEP This step maximizes the expression of AtGORK in the mammalian expression system. Troubleshooting (Table 2).

5. Assemble the codon optimized AtGORK sequences from synthetic oligonucleotides and/or PCR products using the GeneArt $^{\mathrm{TM}}$ Gene Synthesis service offered by ThermoFisher Scientific. $\bullet$ OPTIONAL Alternatively, this step can be carried out using the conventional PCR cloning method.

\section{Cloning, Transformation and Plasmid Purification (4-5 Days)}

6. Clone the optimized $A t G O R K$ fragment into a Gateway ${ }^{\circledR}$ $\mathrm{pDONR}^{\mathrm{TM}} 221$ entry vector.

7. Perform a LR recombination reaction between the entry vector and the pcDNA ${ }^{\mathrm{TM}} 6.2 / \mathrm{cLumio}^{\mathrm{TM}}-\mathrm{DEST}$ or the Vivid Colors ${ }^{\mathrm{TM}}$ pcDNA ${ }^{\mathrm{TM}}$ 6.2/EmGFP-DEST Gateway ${ }^{\circledR}$ vector using the Gateway ${ }^{\circledR}$ LR Clonase ${ }^{\circledR}$ II Enzyme Mix following the manufacturer's protocol.

8. Transform the $\mathrm{pcDNA}^{\mathrm{TM}} 6.2 / \mathrm{cLumi}^{\mathrm{TM}}$-DEST and Vivid Colors ${ }^{\mathrm{TM}}$ pcDNA $^{\mathrm{TM}}$ 6.2/EmGFP-DEST Gateway ${ }^{\circledR}$ expression vectors containing the AtGORK insert into One Shot ${ }^{\mathrm{R}}$ Mach1 ${ }^{\mathrm{TM}}-\mathrm{T} 1^{\mathrm{R}}$ phage-resistant chemically competent E. coli cells following the manufacturer's transformation procedure.

9. Inoculate a single, overnight colony in $5 \mathrm{~mL}$ of selective $\mathrm{LB}$ broth containing $50 \mu \mathrm{g} / \mathrm{mL}$ carbenicillin and shake at $37^{\circ} \mathrm{C}$ overnight before isolating the plasmid.
10. Isolate and purify high quality plasmid DNA using the Invitrogen ${ }^{\mathrm{TM}}$ PureLink ${ }^{\circledR}$ HQ Mini Plasmid Purification kit according to the manufacturer's instructions. CRITICAL STEP This step provides a good yield of high-quality plasmid DNA for use in mammalian cell transfections.

11. Analyze both the plasmid constructs by sequencing to verify that the insertion of $A t G O R K$ into the expression vectors is in-frame and error-free.

\section{Growth and Maintenance of the 293FT Cell Line (2-3 Days)}

- CRITICAL STEP Culture media and trypsin-EDTA solution should be pre-warmed in the water bath at $37^{\circ} \mathrm{C}$.

- CAUTION Handle the cell line as potentially bio-hazardous material under at least Biosafety Level 2 containment.

12. Remove the vial of frozen cells from $-140^{\circ} \mathrm{C}$ freezer and thaw quickly in a $37^{\circ} \mathrm{C}$ water bath.

13. Transfer the cells to $T-75 \mathrm{~cm}^{2}$ culture flask containing $11 \mathrm{~mL}$ of complete medium consisting of Dulbecco's modified Eagle's medium, DMEM (1X) + GlutaMAX $^{\mathrm{TM}}-\mathrm{I}$ supplemented with $10 \%(\mathrm{v} / \mathrm{v})$ fetal bovine serum and $1 \%$ (v/v) penicillin-streptomycin $(10,000 \mathrm{U} / \mathrm{mL})$. CRITICAL STEP Ensure that all solutions and equipment that come in contact with the cells are sterile by performing the work in a laminar flow hood and always practice good aseptic technique.

14. Maintain the cell culture at $37^{\circ} \mathrm{C}$ in a $5 \% \mathrm{CO}_{2}$ humidified growth incubator. Replace with fresh, complete medium $24 \mathrm{~h}$ after seeding. $\bullet$ CRITICAL STEP Replacement with fresh, complete medium upon overnight seeding is important to remove residual DMSO contained in the freezing medium. - CAUTION DMSO is toxic to cell growth.

15. Incubate the cells until they are $80-90 \%$ confluent. -CRITICAL STEP Pass the 293FT cells when they are $\geq 80 \%$ confluent to avoid cell overgrowth.

\section{Transient Transfection and Heterologous Expression of AtGORK in 293FT Cells (1 Day)}

- CRITICAL STEP We recommend using early-passage cells for transfection experiments. Cells should be at the appropriate confluence and at $>90 \%$ viability prior to transfection.

16. Remove all medium from the flask and add $2 \mathrm{~mL}$ of $0.25 \%$ trypsin-EDTA solution to the adherent monolayer and incubate $1-5 \mathrm{~min}$ at $37^{\circ} \mathrm{C}$ in a $5 \% \mathrm{CO}_{2}$ humidified growth incubator until the cells detach. Check the cells under a microscope to confirm that most of the cells have been detached from the bottom surface of the flask. Increase the incubation time if the cells are still attached.

17. Add $6 \mathrm{~mL}$ of complete medium to the cell suspension and mix gently. CRITICAL STEP This step is to inactivate the trypsin activity as serum contains inhibitors of trypsin.

18. Determine cell viability using trypan blue exclusion and total cell count using a cell counter (e.g., Countess ${ }^{\circledR}$ II Automated Cell Counter). 
19. Dilute the cell density to a total of $2.5 \times 10^{5}$ viable cells $/ 2 \mathrm{~mL}$ in pre-warmed complete medium for the transfection protocol. • OPTIONAL the final cell density for transfection protocol varies depending on the purpose of experiment. Here, we recommend an optimal cell density of $2.5 \times 10^{5}$ viable cells $/ 2 \mathrm{~mL}$ in order to select for single cell expressing the channel protein for current-voltage measurements. Troubleshooting (Table 2).

20. Seed the remaining cells at a total density of $1 \times 10^{6}$ viable cells in a $\mathrm{T}-75 \mathrm{~cm}^{2}$ flask containing $11 \mathrm{~mL}$ of pre-warmed complete medium and maintain the cells as adherent monolayer cultures at $37^{\circ} \mathrm{C}$ in a $5 \% \mathrm{CO}_{2}$ incubator for cell establishment.

21. Once the cells have been established, we recommend freezing some cells for storage and for future use by freezing the cells at a density of at least $3 \times 10^{6}$ viable cells/ $\mathrm{mL}$ and at $>90 \%$ viability in labeled cryovials containing the freezing medium. CRITICAL STEP Prepare fresh freezing medium immediately before use.

22. Clean the $12 \mathrm{~mm}$ circle cover glasses by placing the coverslips in a $50 \mathrm{~mL}$ beaker containing acetone and swirl the beaker gently to ensure that all the coverslips are immersed in acetone. Incubate overnight in a fume hood. CAUTION Acetone is a highly flammable and toxic material that should only be used in a fume hood.

23. Discard the acetone solution and wash the coverslips thrice by rinsing with absolute ethanol. Repeat step 22 by replacing acetone with absolute ethanol. CAUTION Ethanol is a highly flammable and toxic solvent that should only be used in a fume hood.

24. Discard the ethanol solution and wash the coverslips thrice by rinsing with sterile water. Dry the clean coverslips by incubating in an oven at $65^{\circ} \mathrm{C}$ overnight. Store the clean coverslips at room temperature.

25. Place four clean coverslips in a well of a 6-well, flat bottom cell culture plate and coat the coverslips with $2 \mathrm{~mL}$ of $50 \mu \mathrm{g} / \mathrm{mL}$ poly-D-lysine hydrobromide at $37^{\circ} \mathrm{C}$ overnight. Discard the poly-D-lysine hydrobromide solution and wash the coated coverslips thrice with sterile water prior to transfection. $\bullet$ CRITICAL STEP Coating of coverslips with poly-D-lysine facilitates the cell attachment to the surface of coverslips by promoting the electrostatic interactions between the cell membrane and the polyamino acids on the culture surface. Troubleshooting (Table 2).

26. We use cationic lipid-based transfection reagents (Felgner and Ringold, 1989), Lipofectamine ${ }^{\circledR} 2000$, Lipofectamine ${ }^{\circledR}$ 3000, and non-liposomal FuGENE ${ }^{\circledR}$ HD formulation to transiently transfect the 293FT cells with $2.5 \mu \mathrm{g}$ of AtGORK plasmid obtained in step 10 according to the respective manufacturer's instructions (Table 1). CRITICAL STEP Equilibrate the transfection reagents to room temperature before use and mix by inverting or through a brief vortex. • OPTIONAL We recommend the use of OPTI-MEM ${ }^{\circledR}$ I (1X) Reduced Serum Medium as diluent in all transfection steps. Alternatively, serum-free DMEM (1X) + GlutaMAX $^{\mathrm{TM}}$-I medium can be used for the transfection protocol. Troubleshooting (Table 2).
TABLE 1 | Lipid-mediated transient transfection experimental parameters and conditions.

\begin{tabular}{llll}
\hline Component per well & FuGENE ${ }^{\circledR}$ HD & \multicolumn{2}{c}{ Lipofectamine ${ }^{\circledR}$} \\
\cline { 3 - 4 } & & $\mathbf{2 0 0 0}$ & $\mathbf{3 0 0 0}$ \\
\hline 293FT cell number/ $2 \mathrm{~mL}$ & $2.5 \times 10^{5}$ cells & $2.5 \times 10^{5}$ cells & $2.5 \times 10^{5}$ cells \\
\hline (i) Transfection reagent & & & \\
OPTI-MEM ${ }^{\circledR}$ I medium & $100 \mu \mathrm{L}$ & $125 \mu \mathrm{L}$ & $125 \mu \mathrm{L}$ \\
Transfection reagent & $10 \mu \mathrm{L}$ & $12.5 \mu \mathrm{L}$ & $7.5 \mu \mathrm{L}$ \\
(ii) DNA component & & & \\
OPTI-MEM ${ }^{\circledR}$ I medium & Up to $100 \mu \mathrm{L}$ & Up to $125 \mu \mathrm{L}$ & Up to $125 \mu \mathrm{L}$ \\
Plasmid DNA & $2.5 \mu \mathrm{g}$ & $2.5 \mu \mathrm{g}$ & $2.5 \mu \mathrm{g}$ \\
*P3000 $^{\mathrm{TM}}$ reagent & $\mathrm{N} / \mathrm{A}$ & $\mathrm{N} / \mathrm{A}$ & $5 \mu \mathrm{L}$ \\
Incubation time at RT & $15 \mathrm{~min}$ & $5 \mathrm{~min}$ & $5 \mathrm{~min}$ \\
\hline
\end{tabular}

*Applicable only for transfections using the Lipofectamine ${ }^{\circledR} 3000$ reagent.

27. The "reverse" transfection method entails adding the DNAlipid complex in a drop-wise manner directly to the cell suspension containing total viable cells of $2.5 \times 10^{5} / 2 \mathrm{~mL}$ in a $15 \mathrm{~mL}$ centrifuge tube. Mix gently by pipetting up and down. Transfer the cell mixture to a well of 6-well culture dish containing the coated coverslips obtained in step 25 . - CRITICAL STEP The DNA-lipid complex should be added in a drop-wise manner directly to the cell suspension without touching the walls of the tube prior to mixing by gentle pipetting and followed by plating and culturing overnight at $37^{\circ} \mathrm{C}$ in a 6 -well culture dish. Troubleshooting (Table 2).

28. Here, we define "standard" transfection as a method entailing the addition of the plasmid DNA and transfection reagent mixture in a drop-wise manner to the adherent 293FT cells that have been seeded at a final viable cell concentration of $2.5 \times 10^{5}$ a day before. $\bullet$ CRITICAL STEP The DNA-lipid complex should be added in a drop-wise manner and distributed homogenously to the adhered cells in the culture dish by gentle swirling without disturbing the adhered cells (Figure S4B).

29. The "double" transfection refers to the combination of both "standard" and "reverse" methods in the following sequence: reverse transfection and incubates overnight, followed by standard transfection on the following day.

30. Incubate the cells at $37^{\circ} \mathrm{C}$ overnight in a $5 \% \mathrm{CO}_{2}$ humidified growth incubator.

\section{In vivo Fluorescence Labeling, Imaging, and Quantification (60 Min)}

31. Use the Lumio ${ }^{\mathrm{TM}}$ Green In-Cell Labeling kit to detect the expression of AtGORK-cLumio ${ }^{\mathrm{TM}}$ in 293FT cells following the manufacturer's instructions. Label the cells transfected with $A t G O R K$-cLumio ${ }^{\mathrm{TM}}$ expression vector obtained in step 30 with $1.25 \mu \mathrm{M}$ of Lumio $^{\mathrm{TM}}$ Green. Incubate the cells at $37^{\circ} \mathrm{C}$ for $30 \mathrm{~min}$, protected from light. CAUTION Lumio $^{\mathrm{TM}}$ Green is a biarsenical labeling reagent, specifically recognizes and binds to the tetracysteine Lumio $^{\mathrm{TM}}$ tag, which strongly fluoresces upon binding to the Lumio ${ }^{\mathrm{TM}}$ tag. 
TABLE 2 | Troubleshooting.

\begin{tabular}{|c|c|c|c|}
\hline Step & Parameters & Recommendation & Comments \\
\hline 3 & Plasmid and label & $\begin{array}{l}\text { Vivid Colors }{ }^{T M} \\
\text { pcDNA }^{T^{T M}} 6.2 / \text { EmGFP- } \\
\text { DEST Gateway }{ }^{\circledR} \\
\text { vector }\end{array}$ & $\begin{array}{l}\text { EmGFP improves } \\
\text { expression of } \\
\text { AtGORK and reduces } \\
\text { background noise } \\
\text { signal (Martin et al., } \\
\text { 2005) }\end{array}$ \\
\hline 4 & Codon optimization & $\begin{array}{l}\text { GeneOptimizer }^{\circledR} \\
\text { software by } \\
\text { ThermoFisher } \\
\text { Scientific }\end{array}$ & $\begin{array}{l}\text { Maximizes the } \\
\text { expression of } \\
\text { AtGORK in the } \\
\text { mammalian } \\
\text { expression system }\end{array}$ \\
\hline 19 & Amount of cells & $2.5 \times 10^{5}$ cells $/ 2 \mathrm{~mL}$ & $\begin{array}{l}\text { Suitable seed amount } \\
\text { to achieve } \\
\text { well-spaced single } \\
\text { cells }\end{array}$ \\
\hline 25 & Coating of cover slip & $\begin{array}{l}\text { Overnight coating } \\
\text { with Poly-D-lysine }\end{array}$ & $\begin{array}{l}\text { Poly-D-lysine is } \\
\text { preferred over } \\
\text { poly-L-lysine because } \\
\text { poly-D-lysine is not } \\
\text { digestible }\end{array}$ \\
\hline 26 & Amount of plasmid & $2.5 \mu \mathrm{g}$ & $\begin{array}{l}\text { Higher plasmid } \\
\text { amount did not } \\
\text { significantly improve } \\
\text { transfection efficiency } \\
\text { and may be toxic to } \\
\text { cells (Lin et al., 2015; } \\
\text { Figure S2) }\end{array}$ \\
\hline 26 & Transfection reagent & Lipofectamine ${ }^{\circledR} 3000$ & $\begin{array}{l}\text { Lipofectamine }{ }^{\circledR} 3000 \\
\text { outperforms } \\
\text { Lipofectamine }{ }^{\circledR} 2000 \\
\text { and FuGENE }{ }^{\circledR} \text { HD }\end{array}$ \\
\hline 27 & Transfection protocol & "Reverse" & $\begin{array}{l}\text { "Reverse" } \\
\text { transfection protocol } \\
\text { saves one additional } \\
\text { day and is generally } \\
\text { preferred for } \\
\text { single-cell } \\
\text { applications as } \\
\text { compared to the } \\
\text { "standard" } \\
\text { transfection }\end{array}$ \\
\hline 34 & Detection & GFP fluorescence & $\begin{array}{l}\text { Requires } \\
\text { fluorescence } \\
\text { microscopy with } \\
\text { fluorescence GFP } \\
\text { filters }\end{array}$ \\
\hline
\end{tabular}

Practice safe precautionary measures by wearing protective clothing, eyewear, and nitrile gloves when handling the Lumio $^{\text {TM }}$ Green reagent. $\bullet$ CRITICAL STEP Prepare fresh Lumio $^{\mathrm{TM}}$ Green solution just before use and keep the solution at room temperature in dark, protected from light.

32. Upon incubation, gently remove the Lumio ${ }^{\mathrm{TM}}$ labeling solution and wash cells once with OPTI-MEM ${ }^{\circledR}$ I medium. Carefully remove and discard the medium.

33. Gently add $20 \mu \mathrm{M}$ of Disperse Blue 3 solution that is supplied with the Lumio ${ }^{\mathrm{TM}}$ In-Cell labeling kit following the manufacturer's protocol to each well. $\bullet$ CRITICAL STEP Do not remove the solution and proceed to fluorescence imaging to detect the labeled AtGORK-cLumio ${ }^{\mathrm{TM}}$ in the presence of Disperse Blue 3 solution to reduce the high background fluorescence (Adams et al., 2002). - CAUTION Disperse Blue 3 solution is a non-fluorescent, hydrophobic dye that may results in eye, and skin irritation. Wear protective clothing, eyewear and nitrile gloves when handling with the solution. • OPTIONAL Due to high background signal resulted from Lumio ${ }^{\mathrm{TM}}$ Green staining, a stringent washing procedure can be carried out by adding low concentrations of thiol-containing reagent using $\beta$-mercaptoethanol that competitively binds to the thiol-binding site thereby increasing the specific labeling of the Lumio $^{\mathrm{TM}}$-tagged proteins (Langhorst et al., 2006).

34. Detect expression of AtGORK-EmGFP directly in 293FT cells transfected with AtGORK-EmGFP plasmid by fluorescence microscopy using the green fluorescence filter at the excitation wavelength from 460 to $500 \mathrm{~nm}$. -CRITICAL STEP Both pcDNA ${ }^{\mathrm{TM}} 6.2 /$ nLumio $^{\mathrm{TM}}$ GW/p64 and Vivid Colors pcDNA6.2/C-terminal tagged EmGFP/GW/CAT plasmids are used as the positive control for transfection efficiency. Troubleshooting (Table 2).

35. Capture three bright-field images from three randomly chosen locations under a $20 \times$ objective lens. Capture also three fluorescence images under the same viewing fields to calculate the percentage of transfection efficiency. On average, a fluorescence image contained several hundred green cells.

36. Using Image J (Schneider et al., 2012), process and analyse the fluorescence and bright-field images according to the methods described previously (Lin et al., 2015) in order to determine the transfection efficiency and the expression levels. Each fluorescence image contains $2560 \times 1920$ pixels and each is assigned a value ranging from 0 to 255 on an 8-bit digital scale using Image J. •CRITICAL STEP Each green fluorescent cell detected represents successful transfection and protein expression.

37. We define transfection efficiency as the number of cells that have fluorescence detectable above background divided by the total number of cells calculated on the corresponding bright-field images and is expressed as a percentage.

38. We estimate the relative expression levels of the protein by measuring the fluorescent intensities (in pixels) of the green fluorescent cells with the assumption that the protein expression in each individual cell is linearly proportional to the amount of the reporter EmGFP or Lumio ${ }^{\mathrm{TM}}$ tag that the cell expressed (Lin et al., 2015).

\section{RNA Extraction, cDNA Synthesis and PCR (1-2 Days)}

39. Perform total RNA extraction followed by cDNA synthesis from the transfected cells obtained in step 30 as described previously (Sagar et al., 2014).

40. Gently wash the transfected cells twice with $2 \mathrm{~mL}$ of cold $1 \mathrm{X}$ PBS solution. Discard the PBS solution.

41. Add $600 \mu \mathrm{L}$ of TRIzol ${ }^{\circledR}$ reagent to the cells and incubate at room temperature for $5 \mathrm{~min}$ to allow cell lysis to occur. 
Gently transfer the cells from the 6-well culture dish to $1.5 \mathrm{~mL}$ microcentrifuge tubes.

42. Add $120 \mu \mathrm{L}$ of chloroform to the lysed cells and gently invert the tubes for $15 \mathrm{~s}$. Incubate on ice for $10 \mathrm{~min}$. Centrifuge at $8000 \mathrm{rpm}$ at $4^{\circ} \mathrm{C}$ for $15 \mathrm{~min}$.

43. Separate the aqueous phase and transfer to new sterile $1.5 \mathrm{~mL}$ microcentrifuge tubes. Add $300 \mu \mathrm{L}$ of 2-Propanol to the aqueous phase and incubate at $-20^{\circ} \mathrm{C}$ overnight to precipitate the RNA.

44. The following day, centrifuge at $8000 \mathrm{rpm}$ at $4^{\circ} \mathrm{C}$ for $30 \mathrm{~min}$. Discard the supernatant.

45. Wash the pellet with $600 \mu \mathrm{L}$ of $75 \%$ (v/v) ethanol. Centrifuge at $8000 \mathrm{rpm}$ at $4^{\circ} \mathrm{C}$ for $20 \mathrm{~min}$. Discard the supernatant. Air-dry the pellet by placing the tube with the lid opened under the laminar hood. Dissolve the pellet in $30 \mu \mathrm{L}$ of DEPC-treated water.

46. Quantify the total RNA concentration using a Nanodrop. Store the RNA at $-80^{\circ} \mathrm{C}$.

47. For synthesis of cDNA, set up a reaction tube consisting of $3 \mu \mathrm{g}$ of RNA obtained in step 46, $250 \mathrm{ng}$ of Oligo-dT primer and $500 \mu \mathrm{M}$ of dNTPs. Incubate the reaction at $65^{\circ} \mathrm{C}$ for $5 \mathrm{~min}$ followed by a brief centrifugation and terminates the reaction by incubating the tube on ice.

48. Set up a cDNA reaction using the Applied Biosystems ${ }^{\mathrm{TM}}$ High-Capacity cDNA Reverse Transcription Kit by adding $1 \mathrm{X}$ first strand reaction Buffer, $5 \mathrm{mM}$ DTT, 200 units SuperScript III RT, and 40 units of RNAse to a final reaction volume of $20 \mu \mathrm{L}$ and run the reaction following the manufacturer's protocol. Store the cDNA at $-20^{\circ} \mathrm{C}$.

49. Perform PCR using the KAPA Taq PCR kit, designed AtGORK PCR forward and reverse primers (Table 3) and PCR cycles according to the manufacturer's instructions to determine the heterologous expression of AtGORK in 293FT cells.

\section{Current-Voltage Recording and Analysis (60 $\mathrm{min})$}

50. Perform whole-cell voltage-clamp recordings from 293FT cells transfected with AtGORK-cLumio ${ }^{\mathrm{TM}}$ and AtGORKEmGFP plasmids respectively, obtained in step 30 as described previously (Lemtiri-Chlieh and Ali, 2013).

51. Using a P-1000 FLAMING/BROWN micropipette puller, make patch-recording pipettes by pulling the pipette from

TABLE 3 | Primers and PCR conditions.

\begin{tabular}{|c|c|c|c|}
\hline Primer name & Sequence $\left(5^{\prime}-3^{\prime}\right)$ & $\operatorname{Tm}\left({ }^{\circ} \mathrm{C}\right)$ & No. of cycle \\
\hline $\begin{array}{l}\text { AtGORK long } \\
\text { forward }\end{array}$ & GGTTCAAACACAGAGAGGTTCAG & 62 & 40 \\
\hline $\begin{array}{l}\text { AtGORK long } \\
\text { reverse }\end{array}$ & TAATTCACGCAAGCTTGACG & 62 & 40 \\
\hline $\begin{array}{l}\text { AtGORK } \\
\text { short forward }\end{array}$ & GGATCAGAAGAGAGTGTGACGTT & 62 & 40 \\
\hline $\begin{array}{l}\text { AtGORK } \\
\text { short reverse }\end{array}$ & CCCTTCAGAAGCCGCG & 62 & 40 \\
\hline
\end{tabular}

thick/standard wall borosilicate glass capillaries. Place the micropipettes in the microforge holder and apply one or two brief heat pulses to smooth the pipette tip.

52. Carefully place one of the coverslips containing the transfected cells obtained in step 30 in the chamber. Find and choose a single healthy cell to patch under the inverted fluorescence microscope.

53. Perform the perfusion system by filling the external $60 \mathrm{~mL}$ syringes with external bath solution. Ensure that there is no air bubble entrapped in the system and that the perfusion is running smoothly at $\sim 1-2 \mathrm{~mL} /$ minute. $\bullet$ CRITICAL STEP Avoid flooding the chamber as the salt in the bath medium can precipitate and thus damage the microscope optics.

54. Fill the recording pipette prepared in step 51 with an intracellular solution and gently tap out any entrapped air bubbles. Apply positive air pressure in the pipette using $1 \mathrm{~mL}$ syringe and ensure that the electrode resistance is between 3 and $5 \mathrm{M} \Omega$. CRITICAL STEP Air bubbles prevent closing of the electronic circuit resulting in a high resistance reading. The internal solution is slightly hypo-osmotic as compared to the bath medium to facilitate the high resistance seal formation.

55. Upon achieving whole-cell configuration, hold the cells at $-52 \mathrm{mV}$.

56. Start recording the $\mathrm{K}^{+}$channel current using the voltageclamp protocol which consists of a series of $1000 \mathrm{~ms}$ long squared voltage depolarization between +120 to $-80 \mathrm{mV}$ in $-20 \mathrm{mV}$ decrements. CRITICAL STEP Cells transfected with $\mathrm{pcDNA}^{\mathrm{TM}} 6.2 / \mathrm{nLumio}^{\mathrm{TM}}-G W / p 64$ and Vivid Colors pcDNA6.2/C-terminal tagged EmGFP/GW/CAT plasmids respectively, are used as the negative control for wholecell recording. To differentiate between intrinsic $\mathrm{K}^{+}$and AtGORK currents, AtGORK conductance was estimated as the difference between steady-state currents (mean current between 900 and $1000 \mathrm{~ms}$ after depolarization) and the current measured in the range of $40-60 \mathrm{~ms}$ from the beginning of the voltage test.

57. Use the MultiClamp ${ }^{\mathrm{TM}} 700 \mathrm{~B}$ microelectrode amplifier to investigate the voltage clamp and current clamp recordings. - CRITICAL STEP All signals were low-pass filtered at $2 \mathrm{kHz}$ before analog-to-digital conversion and were uncorrected for leakage current or capacitive transients.

58. Analyze the data with pClamp software (version 10, Axon Instruments Inc., California, USA) and express the data as mean \pm standard error mean.

\section{Statistical Analysis}

59. Perform statistical analysis using the Student's $t$-test with Microsoft Excel 2010. Set the significance to a threshold of $P<0.05$ and $n$-values represent number of biological replicates.

\section{RESULTS AND DISCUSSION}

Here, we examine several currently used transfection reagents and in-cell fluorescent labeling and detection methods for transient expression of membrane proteins in HEK-293 cells. 
We provide a generally applicable transfection procedure for the expression of membrane proteins for current-voltage measurements using the $A$. thaliana guard cell outwardrectifying $\mathrm{K}^{+}$channel, AtGORK (At5G37500) as an example and discuss the potential pitfalls as well as the general considerations that must be carefully noted throughout the experimental workflow.

\section{An AtGORK-cLumio ${ }^{\mathrm{TM}}$ Tag Fusion has Lower Transfection Efficiency than AtGORK-EmGFP}

In order to select for single cell expressing the channel protein for current-voltage measurement, fluorescent labels were used as indicators for expression of the AtGORK channel in the 293FT cells. We incorporated AtGORK with either a Lumio ${ }^{\mathrm{TM}}$ tag (a molecular weight of $585 \mathrm{Da}$ ) which is a 6 amino acid long cysteine-rich tag separated by a gap of 27 amino acid residues (Figure S1A) or fused the protein with the Emerald Green Fluorescent Protein (EmGFP) of $27 \mathrm{kDa}$ derived from A. victoria GFP at 7 amino acid residues downstream of the C-terminal of AtGORK (Figure S1B). When designing the protein linker, factors such as the length, hydrophobicity and the number of amino acid residues to yield specific structural conformations (e.g., coiled or sheet) that can mitigate structural constrains and thus protein functionality must be considered (for a comprehensive review see: (Chen et al., 2013; Chichili et al., 2013). The Lumio ${ }^{\mathrm{TM}}$ tag contains a tetracysteine motif (Cys-Cys-Pro-Gly-Cys-Cys) that forms an arsenical hairpin detectable by interactions with the membrane-permeant fluorogenic biarsenical labeling reagents (e.g., Lumio ${ }^{\mathrm{TM}}$ Green or Lumio ${ }^{\mathrm{TM}}$ Red) that strongly fluoresces upon binding, thus, enabling labeling and detection of Lumio ${ }^{\mathrm{TM}}$-tagged proteins with high specificity and affinity. Cells transfected with the manufacturer-supplied positive control plasmid pcDNA ${ }^{\mathrm{TM}} 6.2 /$ nLumio $^{\mathrm{TM}}-G W / p 64$ (Figures 1A,B) which is a nucleus-localized transcription factor (human c-myc), have poor transfection efficiency with $<50 \%$ of cells expressing the p64 protein, as indicated by the green fluorescence upon labeling with Lumio ${ }^{\mathrm{TM}}$ Green labeling reagent across all three biological replicates. However, the efficiency was reduced to $<5 \%$ for AtGORK-cLumio ${ }^{\text {TM }}$ expressed in HEK-293 cells. Upon labeling with Lumio ${ }^{\mathrm{TM}}$ green reagent, the intensity of green fluorescence that correlates with the amount of p64-Lumio ${ }^{\mathrm{TM}}$ tagged protein expressed in the transfected cells is around 30-40 pixels while those cells expressing the AtGORK-cLumio ${ }^{\mathrm{TM}}$ channel has < 20 pixels (Figure 1C). Since we detected mRNA transcript of AtGORK-cLumio ${ }^{\mathrm{TM}}$ in the transfected cells (Figure S3), the low fluorescence intensity observed is likely due to a poor copy number of AtGORK protein expressed in the cells and/or poor detection resolution resulting from non-specific binding of the Lumio $^{\mathrm{TM}}$ reagent to the cells which reduces the fluorescent signalto-noise ratio. To reduce the high background, we performed a washing procedure using the recommended $1 \mathrm{X}$ Disperse Blue 3 solution. In addition, we also performed a stringent washing procedure by adding low concentrations of thiolcontaining reagent using $\beta$-mercaptoethanol that competitively bind the thiol-binding site thereby increasing the specific labeling of the Lumio ${ }^{\mathrm{TM}}$-tagged proteins (Langhorst et al., 2006). These procedures however do not overcome the problem of the high background fluorescence, but reduce the specific labeling and hence the overall staining efficiency of the Lumio-tagged proteins. On the other hand, cells transfected with the AtGORK-Vivid Colors ${ }^{\mathrm{TM}}$ pcDNA $^{\mathrm{TM}} 6.2 /$ EmGFP-DEST Gateway ${ }^{\circledR}$ construct yield a higher number of transfected cells (55\%) and pixel intensity (80) (Figure 1D). This suggests firstly, that a fluorescent protein fusion enhances the expression efficiency of AtGORK channel in the HEK-293 cells and/or secondly, that the brightness of EmGFP results in better contrast in terms of resolution in detection and identification of protein of interest due at least in part to the reduced background noise signal (Martin et al., 2005). This AtGORK-EmGFP yields a twofolds higher pixel intensity than that of cells transfected with AtGORK-cLumio ${ }^{\mathrm{TM}}$ plasmid although the transfection efficiency is only marginally higher (1.5-fold), suggesting that in addition to an improved AtGORK protein expression in a fused GFP configuration, the detection resolution is markedly improved and this is consistent with previous reports (Martin et al., 2005) that observed a 90\% improved contrast for GFP detection over biarsenic labels. This point is further supported by the fact that the expression of membrane spanning AtGORK-EmGFP channel yielded a pixel intensity that is higher than that of the soluble p64 transcription factor protein labeled with the Lumio ${ }^{\mathrm{TM}}$ system (Figure 1D). Therefore, we recommend the EmGFP-fusion configuration for the expression and identification of channel proteins in 293FT cells by fluorescence detection methods since the improved contrast is critical for single-cell selection and patch-clamp studies in addition to an improvement in the protein expression efficiency.

Since the expression vector contains both the target gene and the fluorescent marker, cells that appear fluorescent therefore provide direct indication of the expression and localization of the target protein in the cells. This is in contrast to the cotransfection method in which the expression of the marker gene (CD8-alpha or a fluorescent protein) may not have a correlation to the success of transfection efficiency and the targeted protein expression level. However, the fluorescent tag or protein fusion may impose structural constrains that can be detrimental to the functionality of the protein of interest (Giepmans et al., 2006). Here, we generated a construct in which AtGORK is fused with the EmGFP at the C-terminal and separated by a 7 amino acid spacer. The EmGFP reporter is located at 519 amino acids away from the annotated transmembrane regions that form the channel pore at the N-terminal of AtGORK (Figure S1B), and this presumably provides a sufficient spatial separation to avoid structural constrains that may interfere with the biological activity of the channel protein. To validate the functionality of the channel activity of AtGORK, we selected single green fluorescent cells for current-voltage measurements and show that the typical transmembrane whole-cell current recordings of AtGORK ( $I_{\mathrm{GORK}}$ ) were obtained (Figure 2). Current-voltage relationship (from +120 to $-80 \mathrm{mV}$ in $-20 \mathrm{mV}$ increments) profiles were generated from the recorded $I_{\mathrm{GORK}}$ (Figure 2Cii). We also measured currents for non-transfected, single HEK-293 
A

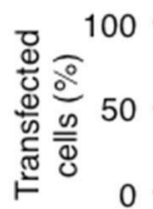

Biol. Repl. 1

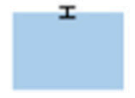

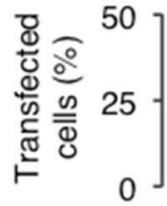

Biol. Repl. 2

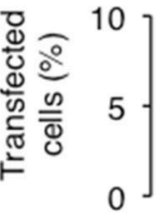

Biol. Repl. 3

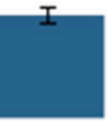

p64
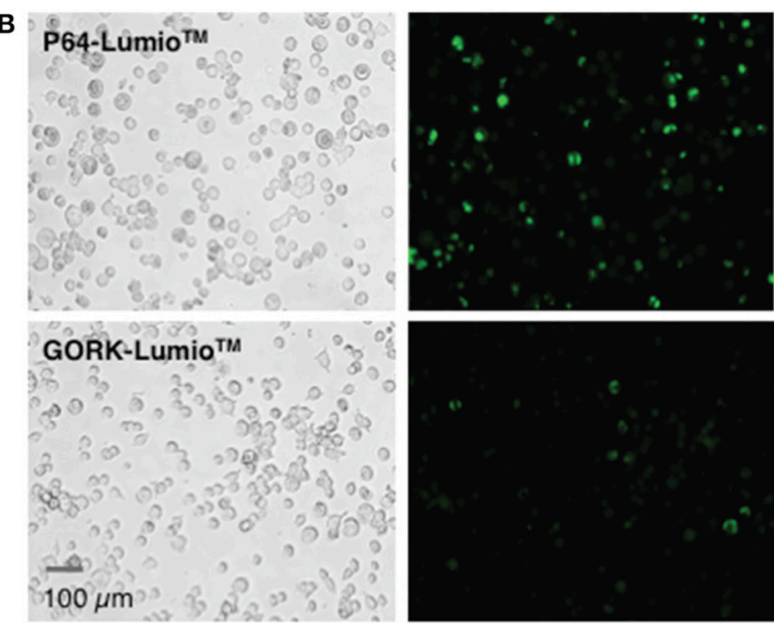

GORK
C

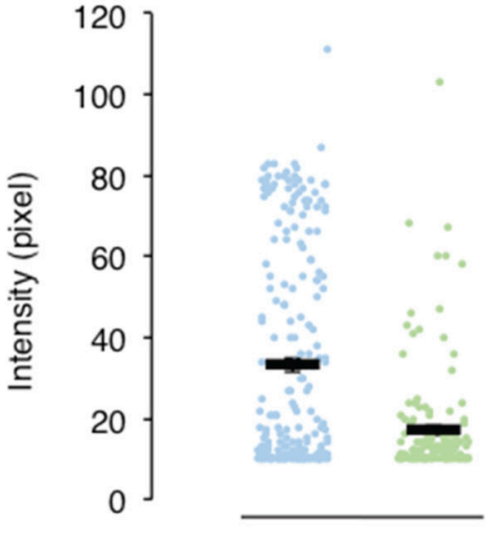

Biol. Repl.

D

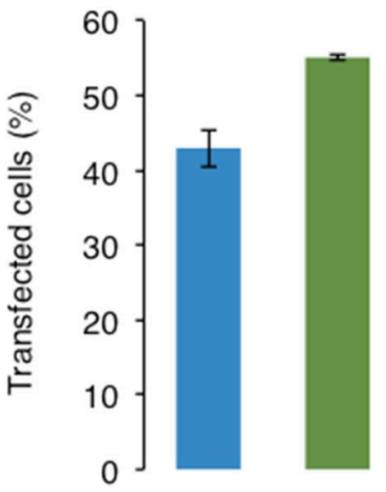

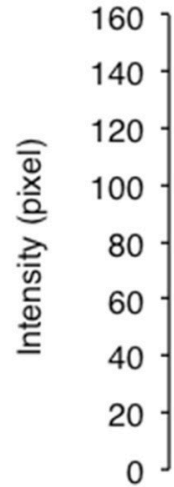

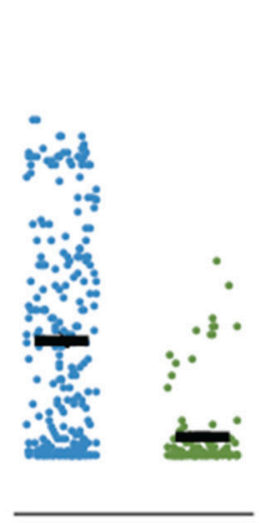

2

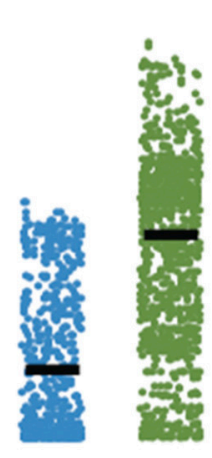

p64-Lumio ${ }^{\mathrm{TM}}$

GORK-GFP

FIGURE 1 | Transfection and expression efficiencies of AtGORK tagged with Lumio ${ }^{\text {TM }}$ and AtGORK fused with EmGFP in HEK-293 cells. (A) HEK-293 cells transfected with AtGORK-cLumio TM expression vector has reduced transfection efficiency as compared to the expression of the positive control p64 that is consistent across all three biological replicates. (B) Representative images showing the poor transfection efficiency of cells transfected with AtGORK-cLumio ${ }^{\mathrm{TM}}$ and the p64 positive control plasmids. (C) The expression of AtGORK in green fluorescence cells is lower than that of p64 using the Lumio ${ }^{\mathrm{TM}}$ system as determined by their pixel intensities. (D) The AtGORK-EmGFP has a higher transfection efficiency and protein expression than that of the nLumio ${ }^{\text {TM }}$-tagged p64 in HEK-293 cells. A typical $20 \times$ magnification of 293FT cell image contains $2560 \times 1920$ pixels and is converted to an 8-bit byte image based on a scale of 0-255 using Image J (Schneider et al., 2012). The lower limit cut-off representing appreciable and above background fluorescence, was set at 10 pixels. Transfection efficiency and protein expression of more than 100 cells in each viewing field were analyzed (see Section Procedure for analysis). 
cells (Figure 2B). These intrinsic currents were shown to be a mixed population of outward-rectifying $\mathrm{K}^{+}$channel endogenous to the HEK-293 cell (Jiang et al., 2002). Though, they are easily recognizable, as they tend to show fast activation and relatively slower inactivation kinetics upon depolarization. On the other hand, $I_{\mathrm{GORK}}$ measured from the cells transfected with AtGORK-EmGFP plasmid demonstrate channel activation with distinctive kinetics (Figure 2C) which are comparable to the known delayed outwardly-rectifying $\mathrm{K}^{+}$-current recorded from either $A$. thaliana guard protoplasts or from $X$. laevis oocytes expressing AtGORK (Ache et al., 2000; Hosy et al., 2003). One can therefore easily distinguish the true voltage and time-dependent activated $I_{\mathrm{GORK}}$ from the other native currents (Figures 2B,C). Therefore, the GFP fusion in this configuration does not alter the functionality of the channel expressed in HEK-293 cells whereas a fusion protein that is very close to the functional domain (e.g., channel pore, catalytic center, or ligand-binding site) is more likely to disrupt the structure or biological activity of the protein (Hoffmann et al., 2010). In some cases, the maturation time of fluorescent proteins may be a limiting factor especially when studying rapid proteinligand or protein-protein interactions (Snapp, 2005). While the use of a smaller label such as the membrane-permeant fluorogenic biarsenical dye fluorescein arsenical hairpin binder $(\mathrm{F} 1 \mathrm{AsH})$ or the alternative red-shifted resorufin arsenical hairpin binder analog $(\mathrm{ReAsH})$ can conceivably overcome structural and the concomitant functionality concerns, these epitopes require labeling with biarsenical dyes that may be toxic to the cells. In addition, non-specific binding of the dye to the hydrophobic regions of the membrane in the cells is commonly associated to the problem of high background staining which may be overcome by an additional washing procedure upon labeling (Martin et al., 2005). Still, in our case, we did not notice a significant improvement in the staining efficiency even after washing. Furthermore, the washing procedure involving thiolcontaining reagents may damage the cells and alternative protein functions (Langhorst et al., 2006). The contrast and cytotoxicity issues commonly associated with the Lumio ${ }^{\mathrm{TM}}$ reagents have been discussed elsewhere (Hoffmann et al., 2010).

\section{Assessment of Commonly Used Transfection Reagents}

In order to evaluate the performance of current commercially available transfection reagents, we transiently transfected the 293FT cells with the AtGORK-EmGFP construct using the standard lipid-mediated transfection reagents, Lipofectamine ${ }^{\circledR}$ 2000, Lipofectamine ${ }^{\circledR}$ 3000, and non-liposomal FuGENE ${ }^{\circledR}$ HD formulation in a "reverse" format (see Section Procedure for definition). Lipofectamine ${ }^{\circledR} 3000$ consistently outperform Lipofectamine ${ }^{\circledR} 2000$ and FuGENE $^{\circledR}$ HD in transfection efficiency, achieving approximately a $70 \%$ transfection rate with AtGORK-EmGFP in comparison to the other two reagents which achieved a rate of about 50\% (Figures 3A,B). The transfected cells exhibit an intensity of green fluorescence that corresponds to the expression levels of AtGORK-EmGFP and is consistently higher when transfected using the Lipofectamine ${ }^{\circledR}$
3000 or FuGENE ${ }^{\circledR}$ HD as compared to the Lipofectamine ${ }^{\circledR}$ 2000 (Figure 3C). This suggests that while FuGENE ${ }^{\circledR}$ HD yields lower transfection efficiency than Lipofectamine ${ }^{\circledR}$ 3000 , the protein expression level is comparable to that of Lipofectamine ${ }^{\circledR} 3000$.

We observed a marked decline in transfection efficiency when the reagents are left at room temperature for prolonged periods of time. We note that the Lipofectamine ${ }^{\circledR}$ and FuGENE ${ }^{\circledR}$ HD formulations should be stored at $4^{\circ} \mathrm{C}$ and should be used immediately after the reagents have been equilibrated to room temperature. Furthermore, it is important to incubate these transfection reagents for the durations and at conditions recommended by their respective manufacturers prior to addition to cells (Table 1). We also noted that these incubation times and conditions should be adhered to as strictly as possible since prolonged incubation times decrease transfection efficiencies. Our results suggest that Lipofectamine ${ }^{\circledR}$ 3000 outperforms Lipofectamine ${ }^{\circledR} 2000$ and FuGENE ${ }^{\circledR}$ HD in transfection efficiency and/or protein expression, which is consistent with the claims of the manufacturer who reported it for HEK-293, HeLa, LNCaP, HepG2, and A549 cell lines, the superiority of Lipofectamine ${ }^{\circledR} 3000$.

\section{Comparison of Different Transfection Protocols}

The three transfection protocols, "standard," "reverse," and "double" (see Section Procedure for definition), were also evaluated for their transfection and expression efficiencies of AtGORK channel in 239FT cells using the Vivid Colors $^{\mathrm{TM}}$ pcDNA $^{\mathrm{TM}} 6.2 /$ EmGFP-DEST Gateway ${ }^{\circledR}$ plasmid and Lipofectamine ${ }^{\circledR} 3000$ reagent. The "reverse" and "double" transfections have similar transfection efficiencies and protein expressions levels (Figure 4). Their transfection efficiency of around $60 \%$ is lower than that achieved with the "standard" transfection (80\%) in two of the three biological replicates (Figures 4 A,B) while only in one of three biological replicates, the "standard" transfection had higher protein expression as deduced from the fluorescence intensities (Figure 4C).

The "standard" transfection protocol while resulting in better transfection efficiency, requires one additional day as compared to the "reverse" transfection because the cells are seeded overnight before the addition of Lipofectamine ${ }^{\circledR} 3000$ reagent and the AtGORK-EmGFP plasmid. Since the cells are allowed to grow for an additional day in the "standard" transfection method, more cells are clumped together and this may complicate single-cell selection for patch-clamp studies. These factors, such as the transfection efficiency, time and cell morphology should be considered case-by-case basis depending on the intended application. As for the transfection of membrane proteins or ion channels in HEK-293 cells, we recommend the "reverse" transfection protocol starting with a seed number of approximately 250,000 cells in a total volume of $2 \mathrm{~mL}$. The "double" transfection protocol may be useful for the transfection of large plasmids $(>10 \mathrm{~kb})$ or choice of cell lines that usually have low transfection efficiency in single transfection. 
A
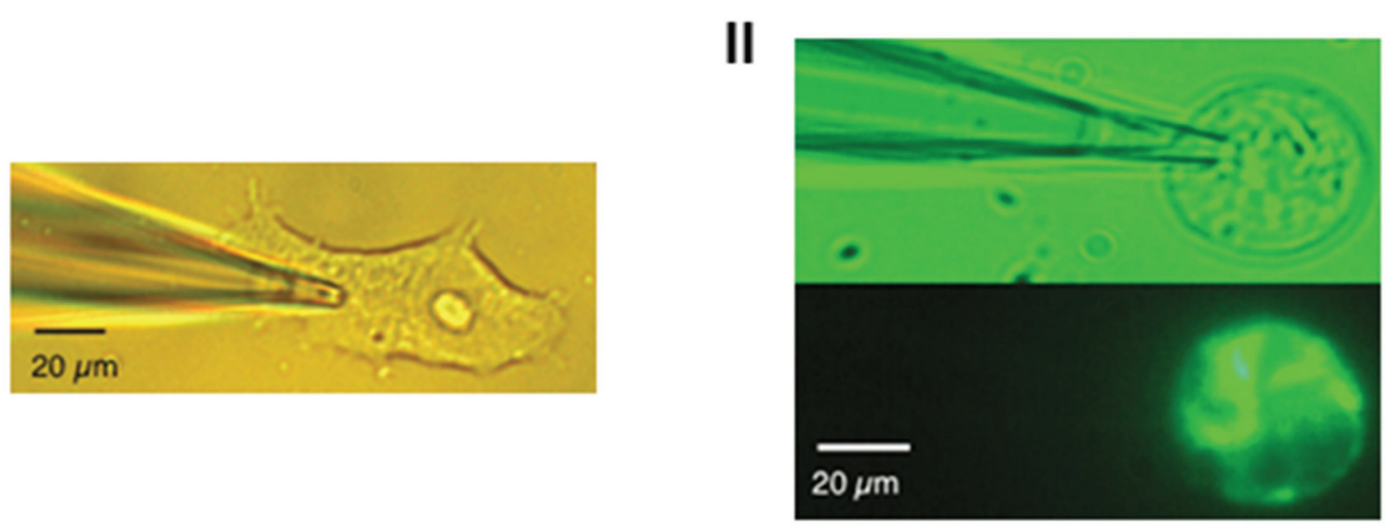

B
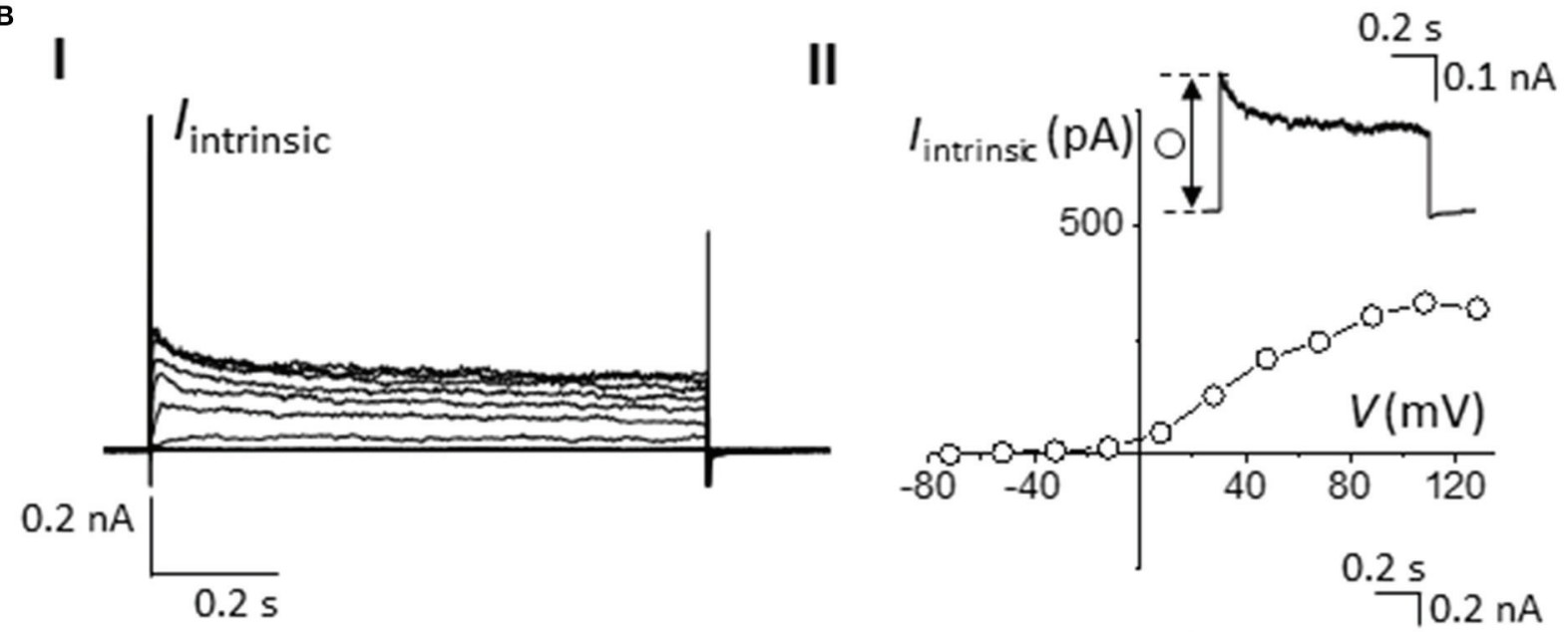

C
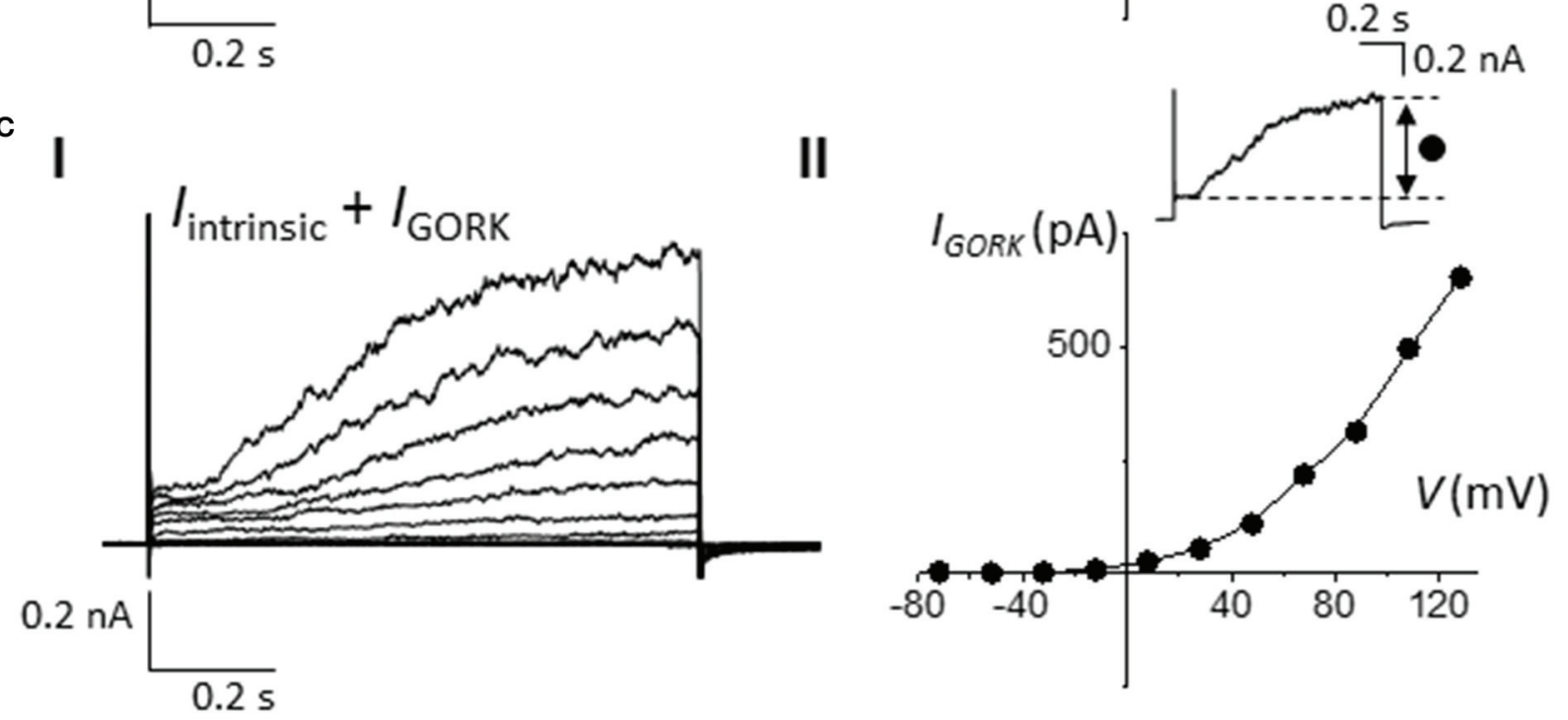

FIGURE 2 | Whole-cell current-voltage measurements of AtGORK-EmGFP in 293FT cells. (A) Bright field and fluorescence images of (i) $293 \mathrm{FT}$ and (ii) AtGORK-EmGFP-expressing 293FT single cell at $20 \times$ magnification field view (scale bar $=20 \mu \mathrm{m}$ ). 293FT cells were transfected with $2.5 \mu \mathrm{g}$ of Vivid Colors ${ }^{\mathrm{TM}}$ pcDNA $^{\mathrm{TM}}$ 6.2/EmGFP-DEST Gateway ${ }^{\circledR}$ expression vector containing the AtGORK insert using Lipofectamine ${ }^{\circledR} 3000$ in a "reverse" format (see Section Procedure for description). (B) Voltage- and time-dependent (i) and I-V plot (ii) properties of the intrinsic $\mathrm{K}^{+}$channels in HEK-293 cells in response to a series of depolarizing square pulse (from a holding potential, $H_{V}=-52 \mathrm{mV}$ in $20 \mathrm{mV}$ increments). Inset: A current showing the fast activation and relatively slower inactivation kinetics of intrinsic $\mathrm{K}^{+}$currents upon depolarization. (C) Whole-cell patch-clamp recordings (i) and I-V plot (ii) of intrinsic $\mathrm{K}^{+}$and AtGORK channels currents, starting from $\mathrm{H}_{V}=-52 \mathrm{mV}$ in $20 \mathrm{mV}$ increments in AtGORK-EmGFP - expressing 293FT single cell. Inset: A representative current demonstrating the slowly activating outward currents of AtGORK upon depolarization. 
A
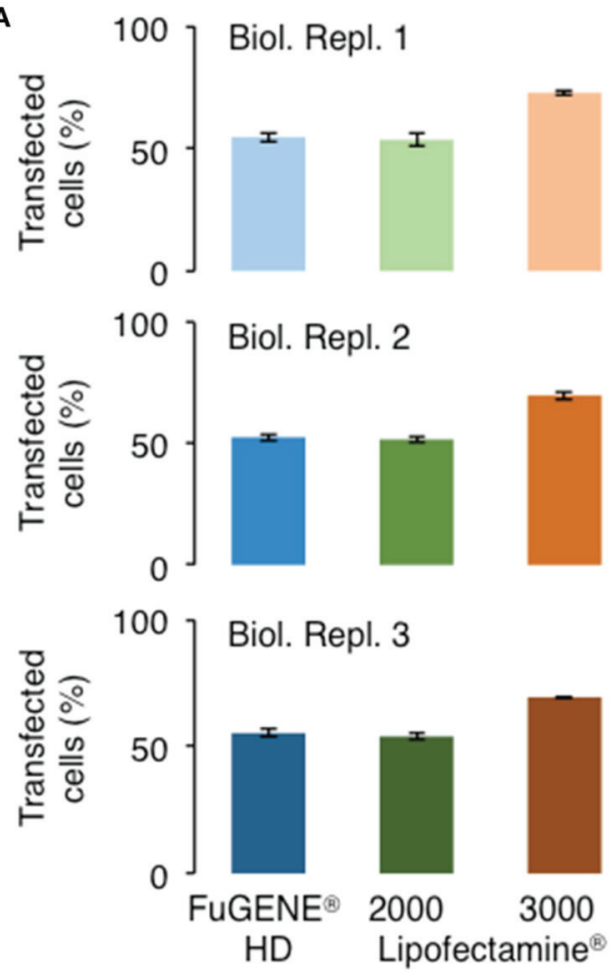
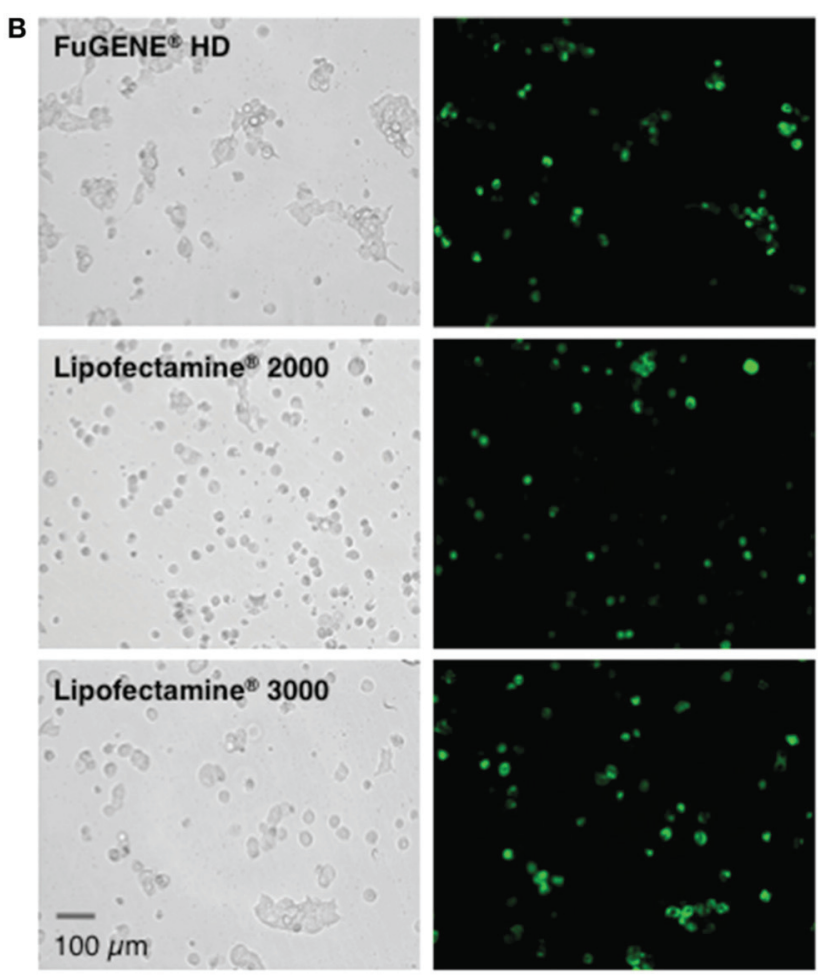

C

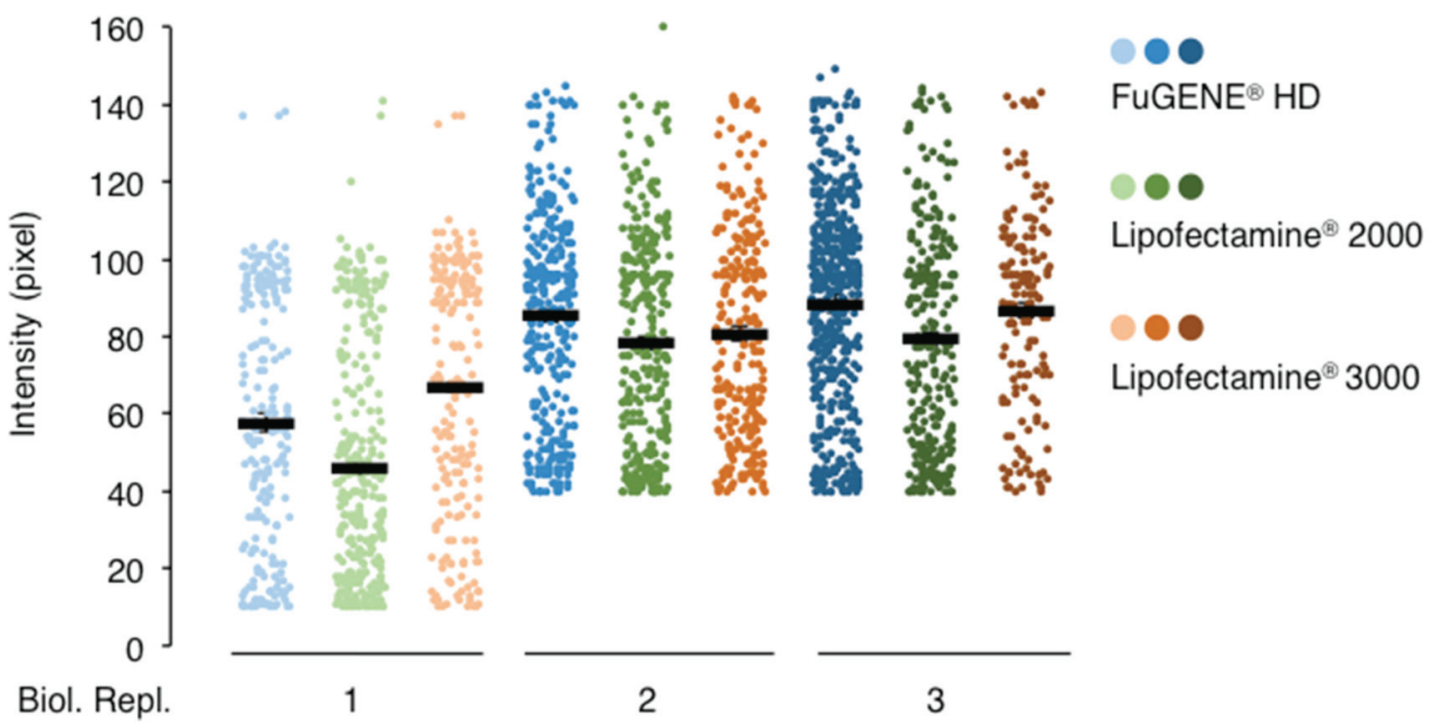

FIGURE 3 | Comparison of different transfection reagents on the transfection and expression efficiencies of AtGORK-EmGFP in HEK-293 cells. HEK-293 cells transfected with AtGORK-EmGFP were used to examine the performance of different transfection reagents in a "reverse" format (see Section Procedure for definition). In general, Lipofectamine ${ }^{\circledR} 3000$ outperforms Lipofectamine ${ }^{\circledR} 2000$ and FuGENE ${ }^{\circledR}$ HD in both transfection efficiency (A,B) and protein expression (C). Lipofectamine ${ }^{\circledR} 2000$ and FuGENE ${ }^{\circledR}$ HD have comparable transfection efficiencies but lower than that of Lipofectamine ${ }^{\circledR} 3000$. FuGENE ${ }^{\circledR}$ HD seems to yield protein expression levels comparable to that of Lipofectamine 3000. A typical $20 \times$ HEK cell image contains $2560 \times 1920$ pixels and is converted to an 8 -bit byte image that on a scale of 0-255 using ImageJ. The lower limit cut-off that represents appreciable and above background fluorescence, was set at 10 pixels for biological replicate 1 but 40 pixels for replicates 2 and 3. Transfection efficiency and protein expression of more than 200 cells in each viewing area were analyzed (see Section Procedure for analysis). 
A
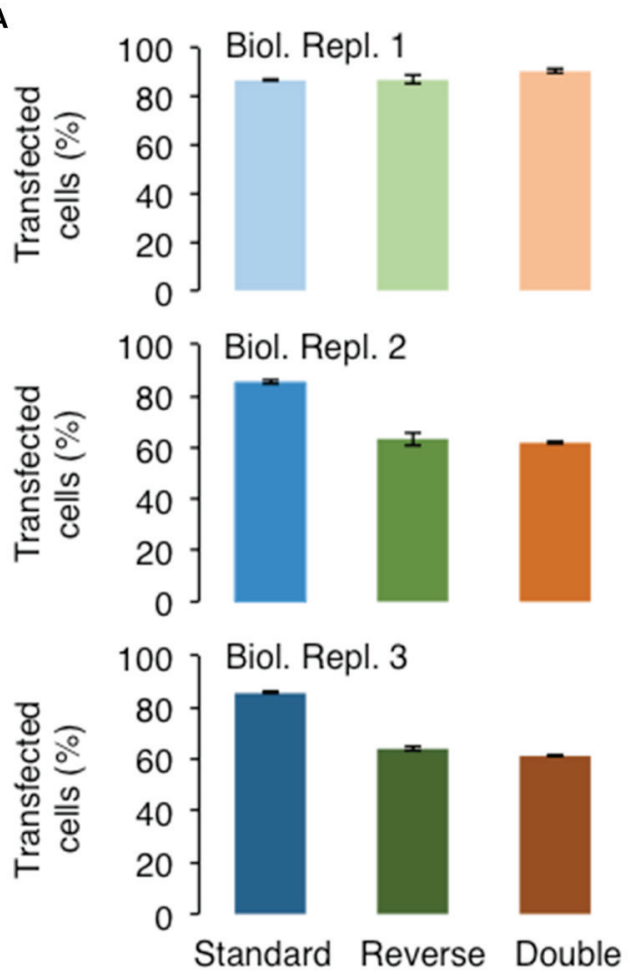

B
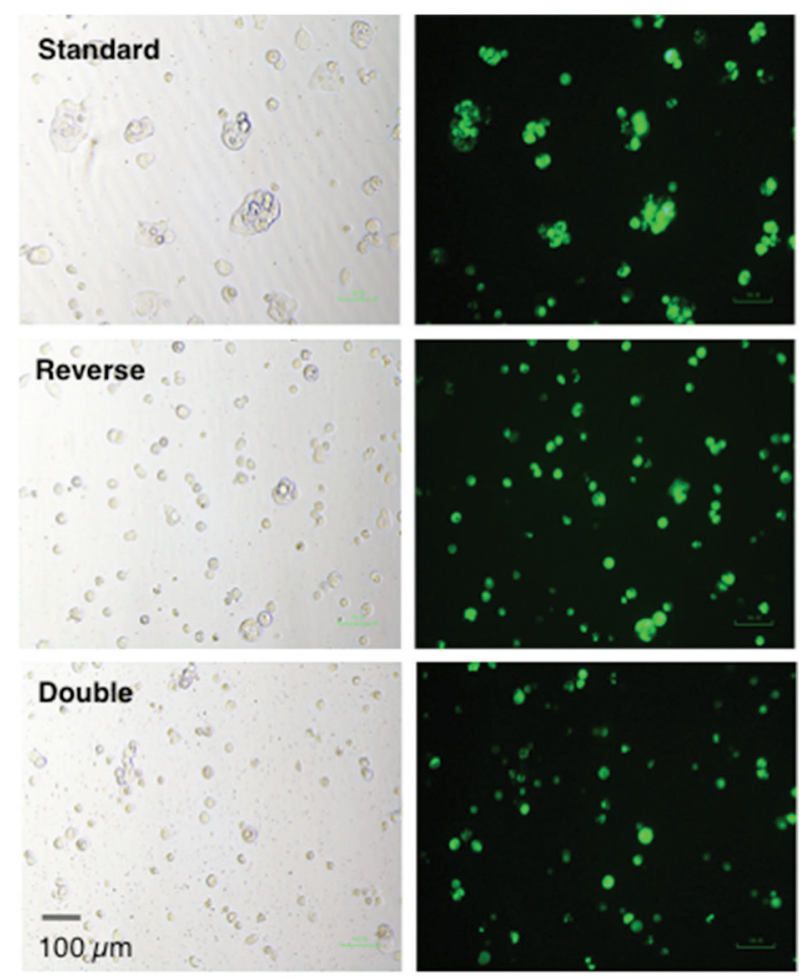

C

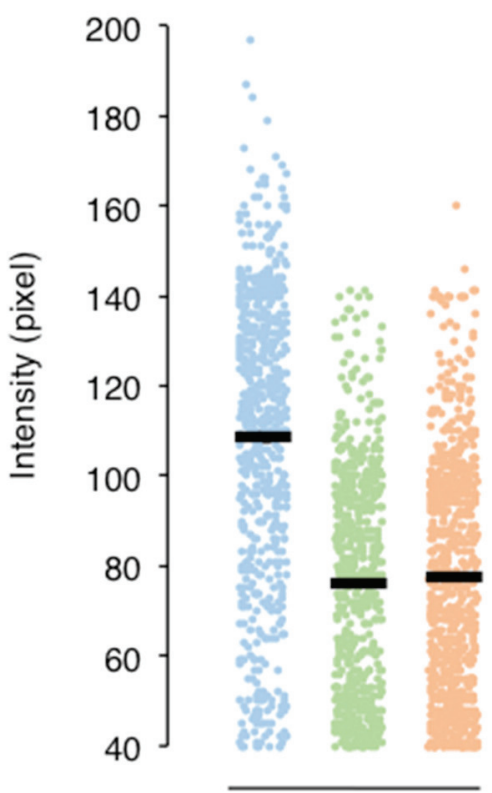

Biol. Repl.

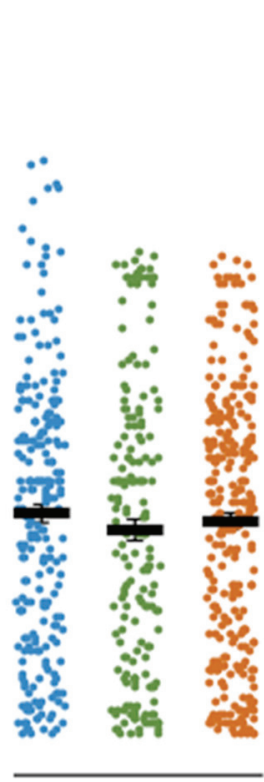

2

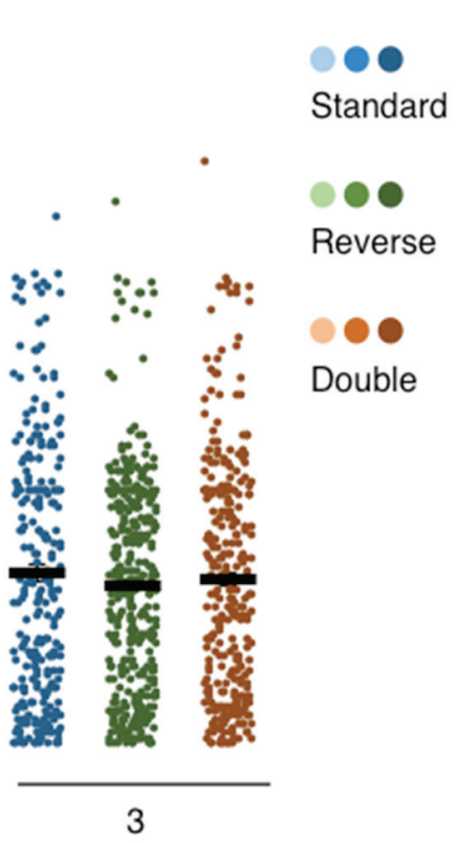

FIGURE 4 | Effect of different transfection methods on the transfection and expression efficiencies of AtGORK-EmGFP in HEK-293 cells. HEK-293 cells transfected with AtGORK-EmGFP were used to examine the performance of different transfection format: "standard," "reverse," and "double" (see Section Procedure for definition) using the Lipofectamine ${ }^{\circledR} 3000$ reagent. The "standard" transfection method outperforms both the "reverse" and "double" transfection format respectively, in 2 out of 3 biological repeats in terms of transfection efficiency (A,B). The "standard" transfection protocol yields higher protein expression levels in only 1 biological replicate but yield comparable expression levels to the other transfection methods in replicates 2 and 3 (C). A typical $20 \times$ HEK cell image contains $2560 \times 1920$ pixels and is converted to an 8-bit byte image that is on a scale of 0-255 using ImageJ. The lower limit cut-off representing appreciable and above background fluorescence, was set at 10 pixels for 40 pixels. Transfection efficiency and protein expression of more than 100 cells in each viewing field were analyzed (see Section Procedure for analysis). 
However, we noted that in the transfection of 293FT cells with AtGORK-EmGFP, the efficiency did not improved with the double transfection protocol since an optimal uptake of plasmids may already have been achieved in single transfection.

\section{A General Protocol for the Expression of Membrane Proteins in HEK-293 Cells for Current-Voltage Measurements}

We detail optimized experimental parameters (Table 2) for high expression of AtGORK channel in 293FT cells for single-cell applications such as electrophysiological characterization and describe the experimental workflow (Figure S4). This authoritative step-by-step protocol serves as a good platform from that, users can conduct informed and less risky targeted optimizations, thus benefiting first time users or those with proteins of unknown properties. Based on this protocol, rational changes can be made in particular to the design of expression vectors with suitable identification tags, as well as the choice of transfection reagents and experimental parameters in order to cater for the expression of membrane proteins in general and/or for other functional characterizations.

In summary, we have described an optimized protocol that serves as a general guide for the transient transfection and expression of a membrane protein in HEK-293 cells for functional characterizations in general and single-cell applications in particular. We demonstrate that the use of a GFP-fused expression construct, Vivid Colors ${ }^{\mathrm{TM}}$ pcDNA $^{\mathrm{TM}} 6.2 /$ EmGFP-DEST Gateway ${ }^{\circledR}$ vector at $2.5 \mu \mathrm{g}$ using Lipofectamine ${ }^{\circledR} 3000$ reagent in a "reverse" format yields a high transfection efficiency, protein expression level as well as optimal detection of AtGORK channels in 293FT cells. We also recommend experimental parameters amendable for other applications including cautionary steps associated with this protocol. We believe that this optimized method will facilitate

\section{REFERENCES}

Ache, P., Becker, D., Ivashikina, N., Dietrich, P., Roelfsema, M. R., and Hedrich, R. (2000). GORK, a delayed outward rectifier expressed in guard cells of Arabidopsis thaliana, is a $\mathrm{K}^{+}$-selective, $\mathrm{K}^{+}$-sensing ion channel. FEBS Lett. 486, 93-98. doi: 10.1016/S0014-5793(00)02248-1

Adams, S. R., Campbell, R. E., Gross, L. A., Martin, B. R., Walkup, G. K., Yao, Y., et al. (2002). New biarsenical ligands and tetracysteine motifs for protein labeling in vitro and in vivo: synthesis and biological applications. J. Am. Chem. Soc. 124, 6063-6076. doi: 10.1021/ja017687n

Allen, S. J., Ribeiro, S., Horuk, R., and Handel, T. M. (2009). Expression, purification and in vitro functional reconstitution of the chemokine receptor CCR1. Protein Expr. Purif. 66, 73-81. doi: 10.1016/j.pep.2009.03.001

Andrell, J., and Tate, C. G. (2013). Overexpression of membrane proteins in mammalian cells for structural studies. Mol. Membr. Biol. 30, 52-63. doi: 10.3109/09687688.2012.703703

Backliwal, G., Hildinger, M., Chenuet, S., Wulhfard, S., De Jesus, M., and Wurm, F. M. (2008a). Rational vector design and multi-pathway modulation of HEK 293E cells yield recombinant antibody titers exceeding $1 \mathrm{~g} / \mathrm{l}$ by transient transfection under serum-free conditions. Nucleic Acids Res. 36, e96. doi: 10.1093/nar/gkn423

Backliwal, G., Hildinger, M., Kuettel, I., Delegrange, F., Hacker, D. L., and Wurm, F. M. (2008b). Valproic acid: a viable alternative to sodium butyrate for enhancing protein expression in mammalian cell cultures. Biotech. Bioeng. 101, 182-189. doi: 10.1002/bit.21882 the physiological and cellular characterization of complex membrane proteins.

\section{AUTHOR CONTRIBUTIONS}

Both $\mathrm{AO}$ and $\mathrm{AW}$ conceived and designed this project. AO, LE, and FL-C conducted the experiments. All authors contributed to the data analyses and writing of the manuscript.

\section{ACKNOWLEDGMENTS}

This research was supported by King Abdullah University of Science and Technology (KAUST) (BAS/1/1013-01-01).

\section{SUPPLEMENTARY MATERIAL}

The Supplementary Material for this article can be found online at: http://journal.frontiersin.org/article/10.3389/fphys. 2016.00300

Figure S1 | Design of AtGORK (At5G37500) plasmid construct. (A) Domain organization of full-length Arabidopsis thaliana GORK (AtGORK) (At5G37500) channel and the insertion of the AtGORK gene into pcDNATM6.2/CLumioTMDEST. (B) Domain organization of full-length Arabidopsis thaliana GORK (AtGORK) (At5G37500) channel and the insertion of the AtGORK gene into Vivid Colors ${ }^{\text {TM }}$ pcDNATM6.2/EmGFP-DEST Gateway ${ }^{\circledR}$ vector.

Figure S2 | Comparison of different amount of AtGORK-cLumio ${ }^{\text {TM }}$ plasmid for transfection.

Figure S3 | mRNA transcript of AtGORK-cLumio ${ }^{\mathrm{TM}}$ heterologously expressed in HEK-293 cells.

Figure S4 | Experimental workflow for heterologous expression of membrane proteins in HEK-293 cells for electrophysiological characterizations. (A) Plasmid design and label selection. (B) Transfection and expression. (C) Fluorescent imaging and quantification. (D) Current-voltage measurement and data analysis.

Baldi, L., Hacker, D. L., Adam, M., and Wurm, F. M. (2007). Recombinant protein production by large-scale transient gene expression in mammalian cells: state of the art and future perspectives. Biotech. Lett. 29, 677-684. doi: 10.1007/s10529-006-9297-y

Bestvater, F., Knoch, T. A., Langowski, J., and Spiess, E. (2002). Construct conversions caused by simultaneous co-transfection: "GFP-walking". Biotechniques 32, 844-850. doi: 10.3410/f.1008665.109707

Bollin, F., Dechavanne, V., and Chevalet, L. (2011). Design of experiment in CHO and HEK transient transfection condition optimization. Protein Exp. Purif. 78, 61-68. doi: 10.1016/j.pep.2011.02.008

Chaudhary, A., Srivastava, S., and Garg, S. (2011). Development of a software tool and criteria evaluation for efficient design of small interfering RNA. Biochem. Biophys. Res. Commun. 404, 313-320. doi: 10.1016/j.bbrc.2010.11.114

Chen, X., Zaro, J. L., and Shen, W. C. (2013). Fusion protein linkers: property, design and functionality. Adv. Drug Deliv. Rev. 65, 1357-1369. doi: 10.1016/j.addr.2012.09.039

Cherel, I., Michard, E., Platet, N., Mouline, K., Alcon, C., Sentenac, H., et al. (2002). Physical and functional interaction of the Arabidopsis $\mathrm{K}^{+}$channel AKT2 and phosphatase AtPP2CA. Plant Cell 14, 1133-1146. doi: 10.1105/tpc. 000943

Chichili, V. P. R., Kumar, V., and Sivaraman, J. (2013). Linkers in the structural biology of protein-protein interactions. Protein Sci. 22, 153-167. doi: $10.1002 /$ pro. 2206

Claassen, S., Schwarzer, S., Ludwig, J., and Zunkler, B. J. (2008). Electrophysiological and fluorescence microscopy studies with HERG 
channel/EGFP fusion proteins. J. Membr. Biol. 222, 31-41. doi: 10.1007/s00232-008-9101-0

Dalton, A. C., and Barton, W. A. (2014). Over-expression of secreted proteins from mammalian cell lines. Protein Sci. 23, 517-525. doi: 10.1002/pro.2439

Ehlers, M. D., Zhang, S., Bernhadt, J. P., and Huganir, R. L. (1996). Inactivation of NMDA receptors by direct interaction of calmodulin with the NR1 subunit. Cell 84, 745-755. doi: 10.1016/S0092-8674(00)81052-1

Fan, S., Maguire, C. A., Ramirez, S. H., Bradel-Tretheway, B., Sapinoro, R., Sui, Z., et al. (2005). Valproic acid enhances gene expression from viral gene transfer vectors. J. Virol. Methods 125, 23-33. doi: 10.1016/j.jviromet.2004.11.023

Felgner, P. L., and Ringold, G. M. (1989). Cationic liposome-mediated transfection. Nature 337, 387-388. doi: 10.1038/337387a0

Fortin, M., and Hugo, P. (1999). Surface antigen detection with nonfluorescent, antibody-coated microbeads: an alternative method compatible with conventional fluorochrome-based labeling. Cytometry 36, 27-35.

Gaietta, G., Deerinck, T. J., Adams, S. R., Bouwer, J., Tour, O., Laird, D. W., et al. (2002). Multicolor and electron microscopic imaging of connexin trafficking. Science 296, 503-507. doi: 10.1126/science. 1068793

Gan, L., Alexander, J. M., Wittelsberger, A., Thomas, B., and Rosenblatt, M. (2006). Large-scale purification and characterization of human parathyroid hormone1 receptor stably expressed in HEK293S GnTI- cells. Protein Expr. Purif. 47, 296-302. doi: 10.1016/j.pep.2005.11.004

Giepmans, B. N., Adams, S. R., Ellisman, M. H., and Tsien, R. Y. (2006). The fluorescent toolbox for assessing protein location and function. Science 312, 217-224. doi: 10.1126/science. 1124618

Griffin, B. A., Adams, S. R., and Tsien, R. Y. (1998). Specific covalent labeling of recombinant protein molecules inside live cells. Science 281, 269-272. doi: $10.1126 /$ science.281.5374.269

Gustafsson, C., Govindarajan, S., and Minshull, J. (2004). Codon bias and heterologous protein expression. Trends Biotechnol. 22, 346-353. doi: 10.1016/j.tibtech.2004.04.006

Hoffmann, C., Gaietta, G., Bunemann, M., Adams, S. R., Oberdorff-Maass, S., Behr, B., et al. (2005). A FlAsH-based FRET approach to determine G proteincoupled receptor activation in living cells. Nat. Methods 2, 171-176. doi: $10.1038 /$ nmeth 742

Hoffmann, C., Gaietta, G., Zurn, A., Adams, S. R., Terrillon, S., Ellisman, M. H., et al. (2010). Fluorescent labeling of tetracysteine-tagged proteins in intact cells. Nat. Protoc. 5, 1666-1677. doi: 10.1038/nprot.2010.129

Hosy, E., Vavasseur, A., Mouline, K., Dreyer, I., Gaymard, F., Poree, F., et al. (2003). The Arabidopsis outward $\mathrm{K}^{+}$channel GORK is involved in regulation of stomatal movements and plant transpiration. Proc. Natl. Acad. Sci. U.S.A. 100, 5549-5554. doi: 10.1073/pnas.0733970100

Hua, B. G., Mercier, R. W., Leng, Q., and Berkowitz, G. A. (2003). Plants do it differently. A new basis for potassium/sodium selectivity in the pore of an ion channel. Plant Physiol. 132, 1353-1361. doi: 10.1104/pp.103.020560

Huang, N., Lian, J. F., Huo, J. H., Liu, L. Y., Ni, L., Yang, X., et al. (2011). The EGFP/hERG fusion protein alter the electrophysiological properties of hERG channels in HEK293 cells. Cell Biol. Int. 35, 193-199. doi: 10.1042/CBI20100022

Jager, V., Bussow, K., Wagner, A., Weber, S., Hust, M., Frenzel, A., et al. (2013). High level transient production of recombinant antibodies and antibody fusion proteins in HEK293 cells. BMC Biotech. 13:52. doi: 10.1186/1472-6750-13-52

Jäger, V., Büssow, K., and Schirrmann, T. (2015). "Transient recombinant protein expression in mammalian cells," in Animal Cell Culture, ed M. Al-Rubeai (Switzerland: Springer International Publishing), 27-64. doi: 10.1007/978-3319-10320-4_2

Jiang, B., Sun, X., Cao, K., and Wang, R. (2002). Endogenous Kv channels in human embryonic kidney (HEK-293) cells. Mol. Cell. Biochem. 238, 69-79. doi: 10.1023/A:1019907104763

Ju, W., Morishita, W., Tsui, J., Gaietta, G., Deerinck, T. J., Adams, S. R., et al. (2004). Activity-dependent regulation of dendritic synthesis and trafficking of AMPA receptors. Nat. Neurosci. 7, 244-253. doi: 10.1038/nn1189

Jurman, M. E., Boland, L. M., Liu, Y., and Yellen, G. (1994). Visual identification of individual transfected cells for electrophysiology using antibody-coated beads. Biotechniques 17, 876-881.

Lacombe, B., Pilot, G., Michard, E., Gaymard, F., Sentenac, H., and Thibaud, J. B. (2000). A shaker-like $\mathrm{K}^{+}$channel with weak rectification is expressed in both source and sink phloem tissues of Arabidopsis. Plant Cell 12, 837-851. doi: $10.1105 /$ tpc.12.6.837
Langhorst, M. F., Genisyuerek, S., and Stuermer, C. A. (2006). Accumulation of FlAsH/Lumio Green in active mitochondria can be reversed by beta-mercaptoethanol for specific staining of tetracysteine-tagged proteins. Histochem. Cell Biol. 125, 743-747. doi: 10.1007/s00418-005-0136-3

Lemtiri-Chlieh, F., and Ali, R. (2013). Characterization of heterologously expressed transporter genes by patch- and voltage-clamp methods: application to cyclic nucleotide-dependent responses. Methods Mol. Biol. 1016, 67-93. doi: 10.1007/978-1-62703-441-8_6

Leng, Q., Mercier, R. W., Hua, B. G., Fromm, H., and Berkowitz, G. A. (2002). Electrophysiological analysis of cloned cyclic nucleotide-gated ion channels. Plant Physiol. 128, 400-410. doi: 10.1104/pp.010832

Lin, C. Y., Huang, Z., Wen, W., Wu, A., Wang, C., and Niu, L. (2015). Enhancing protein expression in HEK-293 cells by lowering culture temperature. PLoS ONE 10:e0123562. doi: 10.1371/journal.pone.0123562

Mariati, Ho, S. C., Yap, M. G., and Yang, Y. (2010). Evaluating post-transcriptional regulatory elements for enhancing transient gene expression levels in CHO K1 and HEK293 cells. Protein Expr. Purif. 69, 9-15. doi: 10.1016/j.pep.2009.08.010

Martin, B. R., Giepmans, B. N., Adams, S. R., and Tsien, R. Y. (2005) Mammalian cell-based optimization of the biarsenical-binding tetracysteine motif for improved fluorescence and affinity. Nat. Biotechnol. 23, 1308-1314. doi: 10.1038/nbt1136

Nettleship, J. E., Ren, J., Rahman, N., Berrow, N. S., Hatherley, D., Barclay, A. N., et al. (2008). A pipeline for the production of antibody fragments for structural studies using transient expression in HEK 293T cells. Protein Expr. Purif. 62, 83-89. doi: 10.1016/j.pep.2008.06.017

Rudner, L., Nydegger, S., Coren, L. V., Nagashima, K., Thali, M., and Ott, D. E. (2005). Dynamic fluorescent imaging of human immunodeficiency virus type 1 gag in live cells by biarsenical labeling. J. Virol. 79, 4055-4065. doi: 10.1128/JVI.79.7.4055-4065.2005

Sagar, S., Esau, L., Moosa, B., Khashab, N. M., Bajic, V. B., and Kaur, M. (2014). Cytotoxicity and apoptosis induced by a plumbagin derivative in estrogen positive MCF-7 breast cancer cells. Anticancer Agents Med. Chem. 14, 170-180. doi: 10.2174/18715206113136660369

Schneider, C. A., Rasband, W. S., and Eliceiri, K. W. (2012). NIH Image to ImageJ: 25 years of image analysis. Nat. Methods 9, 671-675. doi: 10.1038/nmeth.2089

Snapp, E. (2005). Design and use of fluorescent fusion proteins in cell biology. Curr. Protoc. Cell Biol. Chapter 21, Unit 21.24. doi: 10.1002/0471143030.cb2104s27

Swanson, G. T., Kamboj, S. K., and Cull-Candy, S. G. (1997). Single-channel properties of recombinant AMPA receptors depend on RNA editing, splice variation, and subunit composition. J. Neurosci. 17, 58-69.

Thomas, P., and Smart, T. G. (2005). HEK293 cell line: a vehicle for the expression of recombinant proteins. J. Pharmacol. Toxicol. Methods 51, 187-200. doi: 10.1016/j.vascn.2004.08.014

Tour, O., Meijer, R. M., Zacharias, D. A., Adams, S. R., and Tsien, R. Y. (2003). Genetically targeted chromophore-assisted light inactivation. Nat. Biotechol. 21, 1505-1508. doi: 10.1038/nbt914

Tsien, R. Y. (1998). The green fluorescent protein. Annu. Rev. Biochem. 67, 509-544. doi: 10.1146/annurev.biochem.67.1.509

Wulhfard, S., Tissot, S., Bouchet, S., Cevey, J., De Jesus, M., Hacker, D. L., et al. (2008). Mild hypothermia improves transient gene expression yields several fold in Chinese hamster ovary cells. Biotechnol. Prog. 24, 458-465. doi: $10.1021 / \mathrm{bp} 070286 \mathrm{c}$

Wurm, F. M. (2004). Production of recombinant protein therapeutics in cultivated mammalian cells. Nat. Biotechnol. 22, 1393-1398. doi: 10.1038/ nbt1026

Conflict of Interest Statement: The authors declare that the research was conducted in the absence of any commercial or financial relationships that could be construed as a potential conflict of interest.

Copyright (c) 2016 Ooi, Wong, Esau, Lemtiri-Chlieh and Gehring. This is an openaccess article distributed under the terms of the Creative Commons Attribution License (CC BY). The use, distribution or reproduction in other forums is permitted, provided the original author(s) or licensor are credited and that the original publication in this journal is cited, in accordance with accepted academic practice. No use, distribution or reproduction is permitted which does not comply with these terms. 